\title{
Recent and active deformation pattern off the easternmost Algerian margin, Western Mediterranean Sea: New evidence for contractional tectonic reactivation
}

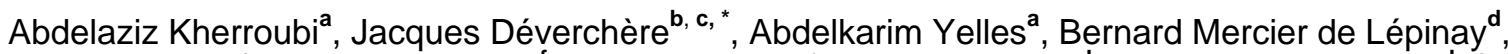
Anne Domzig ${ }^{\mathrm{e}}$, Antonio Cattaneo $^{\mathfrak{f}}$, Rabah Bracène $^{\mathbf{g}}$, Virginie Gaullier ${ }^{\mathrm{h}}$ and David Graindorge $\mathrm{e}^{\mathbf{b}, \mathbf{c}}$
\end{abstract}

${ }^{a}$ C.R.A.A.G. (Centre de Recherche en Astronomie, Astrophysique et Géophysique), BP 63, Bouzaréah, 16340, Algiers, Algeria

${ }^{\mathrm{b}}$ Université Européenne de Bretagne, France

c Université de Brest; CNRS, UMR 6538 Domaines Océaniques, Institut Universitaire Européen de la Mer, Place Copernic, 29280 Plouzané, France

dUMR 6526 CNRS Géosciences Azur, Université de Nice Sophia-Antipolis, 06560 Valbonne, France

e Laboratoire de Planétologie \& Géodynamique, UMR 6112 CNRS, Université de Nantes, BP 92205, 44322, Nantes, France

${ }^{\mathrm{f}}$ IFREMER, Centre de Brest, Laboratoire Environnements Sédimentaires, 29280 Plouzané, France

g SONATRACH, Recherche \& Exploration, Boumerdes, Algeria

h LEGEM (Laboratoire d'Etudes des GéoEnvironnements Marins), EA 3678, Université de Perpignan Via, Domitia, 52 Avenue Paul Alduy, 66860 Perpignan, France

*: Corresponding author : Jacques Déverchère, email address : jacques.deverchere@univ-brest.fr

\begin{abstract}
:
We describe for the first time a set of large active thrusts and folds near the foot of the easternmost Algerian margin, Western Mediterranean, from swath bathymetry and high-resolution seismic data acquired in 2005 during the Maradja2/Samra cruise. This active system resumes a previous passive margin and creates growth strata deposition on the limbs of large folds, resulting in the development of perched basins at the foot of the margin since less than $\sim 1 \mathrm{Ma}$. They form a set of overlapping fault segments verging toward the Algerian basin, in a way similar to what has been observed off eastern Algiers on the rupture zone of the $2003 \mathrm{Mw} 6.8$ Boumerdes earthquake. The horizontal shortening rate across large folds is estimated to be of the order of $1 \mathrm{~mm} / \mathrm{yr}$. Although no historical earthquakes are reported here, these fault segments could have been responsible for large $(M \sim 7.5)$ events in the past. This young tectonic system further supports the hypothesis of subduction inception of the Neogene oceanic lithosphere in the context of the Africa-Eurasia convergence.
\end{abstract}

Keywords: Algerian margin; Annaba; active faulting; folding; growth strata; seismic hazards; seismic reflection; Africa-Eurasia convergence; subduction inception 


\section{Introduction}

Northern Algeria is located at the plate boundary between Eurasia and Africa, and is one of the most seismically active regions of the Mediterranean (e.g. [Buforn et al., 1995], [Stich et al., 2003] and [Stich et al., 2006]; Fig. 1). The tectonic evolution of this region results from the convergence between the European and African plates (e.g. Argus et al., 1989), marked by the Miocene ( $15 \mathrm{Ma}$ ) cessation of subduction of the Tethyan Ocean across the west-Mediterranean subduction zone (Faccenna et al., 2004) and the birth of an Alpine-type orogen which bounds Northern Africa (Auzende et al., 1973), namely the Rif and Tell-Atlas mountains. Today, this area undergoes slow-rate contractional deformation distributed over a relatively wide area ([Frizon de Lamotte et al., 2000] and [Serpelloni et al., 2007]). The convergence rate of Eurasia and Africa is about $5 \mathrm{~mm} / \mathrm{yr}$ at the longitude of Algiers, and increases up to $8 \mathrm{~mm} / \mathrm{yr}$ near Tunisia (Calais et al., 2003). This geodynamical setting would favor an initiation of subduction of the Neogene oceanic lithosphere of the Mediterranean Sea ([Auzende et al., 1973] and Auzende et al., 1975 J.-M. Auzende, J. Bonnin and J.L. Olivet, La marge nord-africaine considérée comme marge active, Bull. Soc. Géol. Fr. 17 (7) (1975), pp. 486-495.[Auzende et al., 1975]), a process that is still poorly documented worldwide and poses important questions on the evolution of lithospheric plates (e.g. [Cloetingh et al., 1982], [Stern, 2004] and [Gurnis et al., 2004]). Moderate to large earthquakes often occurred in the historical and instrumental periods (Fig. 1), such as the 1980 (Ms 7.3) El Asnam or the 2003 (Mw 6.8) Boumerdes earthquakes (e.g. Roussel, 1973; e.g. Stich et al., 2006). Onshore, active faults are concentrated in a relatively wide strip in the northern part of the country. They define a series of NE-SW trending folds and reverse faults affecting Neogene and Quaternary basins and their flanks (Morel and Meghraoui, 1996). Recently, GPS measurements and modelling have shown that part of the convergence between Africa and Europe is accommodated offshore (e.g. [Stich et al., 2006] and [Serpelloni et al., 2007]): a transect from Algeria to Spain (through the Balearic islands) at the longitude of Algiers argues for $\sim 3 \mathrm{~mm} / \mathrm{yr}$ of shortening on land in North Algeria and $\sim 1.5$ $\mathrm{mm} / \mathrm{yr}$ of shortening offshore in a $\mathrm{N}^{2} 50^{\circ} \mathrm{E}$ azimuth (Stich et al., 2006). However, little is known on the geometry, style, timing and spatial distribution of this deformation.

Two oceanographic surveys (Maradja, 2003; Maradja2/Samra, 2005) have covered from west to east the entire Algerian margin. From the Maradja data analysis, a series of active north-verging reverse faults and folds appear to develop recently at the foot of the central Algerian margin in a flat-to-ramp overall geometry (Déverchère et al., 2005), whereas in the western part, recent deformation seems more related to transcurrent movements (Domzig et al., 2006). These new results clearly indicate that a significant part of the AfricaEurasia plate convergence in Algeria has been indeed accommodated offshore in recent times. Although the convergence rate in the eastern part of Algeria is predicted to be relatively high compared to Central and Western Algeria, this area (and especially the region off Annaba) has received little attention until now. This is probably related to the fact that no large historical earthquake is reported there in the last $1300 \mathrm{yr}$, oppositely to the Algiers region (e.g. [Ambraseys and Vogt, 1988], [Harbi et al., 2004] and [Yelles et al., 2006]). The aim of this paper is to contribute to fill this gap of knowledge using a new data set from the Maradja2/Samra cruise, which has covered the eastern Algerian margin from Dellys to Annaba (Fig. 2). We focus here on the evidence for fault and fold development and on the style of deformation (compressive, strike-slip), trying to determine relationships with the past seismic activity and with the previous orogenic history, and to highlight the possible mechanisms which might concentrate deformation at the ocean-continent transition. The identification of structures that might be able to generate large earthquakes could also help to forecast future geological hazards. 


\section{Geology and seismicity background of the Annaba region}

Figure 2 shows the geological setting of North-East of Algeria. This part of the African continent is mostly made of a segment of the Alpine belt that extends from Gibraltar to Calabria. These Alpine units, also called Maghrebides (Durand-Delga, 1978; Wildi, 1983), are about $100 \mathrm{~km}$ wide and are mainly made of the south- or southeast-verging Tellian zones (Figure 2). The Tellian zones constitute the External Zones of the belt and overthrust the Atlas foreland (Vila, 1980; Bouillin, 1986; Frizon de Lamotte et al., 2000, and references therein). The flysch units (Massylian, Mauretanian, and Numidian) and the Internal Zones of the belt, made of Hercynian or older basement and its sedimentary cover, overthrust the External Zones (Figure 2).

This belt of Northern Algeria has recorded a complex Alpine collisional process involving both Eocene-Oligocene crustal thickening and Miocene syn-metamorphic extension synchronous to the onset of opening of the Western Mediterranean basins (Peucat et al., 1996; Saadallah and Caby, 1996) and of the Tyrrhenian sea (Mascle et al., 2001). The Internal Zones form several discontinuous massifs scattered along the coast of central Algeria, including the Lesser Kabylia, the Great Kabylia, and the Algiers massifs. They are assumed to correspond to the splitting of the forearc of the Miocene European plate that has migrated towards the south in the subduction rollback process (e.g., Faccenna et al., 2004). The alignment of these massifs is prolonged offshore to the east as a submerged fold-andthrust belt between Sicily and Tunisia (Tricart et al. 1994; Mascle et al., 2001). The Lesser Kabylia ("Petite Kabylie") has undergone a polyphased tectono-metamorphic history (Vila, 1980) with at least two main orogenic phases (Hercynian and Alpine), and a late event related to the intrusion of Miocene granites (20-16 Ma) followed by low-temperature activity until 7-10 Ma (Peucat et al., 1996). Intrusive bodies at the coastline form well known rounded massifs, such as the Collo and the Cap de Fer ones (Figures 2 and 3).

Although several pieces of evidence exist for a recent (Plio-Quaternary) reactivation of the margins at the contact of the European and African plates, especially in the surroundings of the Alboran Sea (Comas et al., 1999, Augier et al., 2005), the gulf of Cadiz (Zitellini et al., 2004), and the southern Tyrrhenian Sea (Goes et al., 2004; Billi et al., 2007), the exact timing, the possible diachroneity of deformation, and its spatial extent, remain controversial and poorly argued, especially in central and eastern Algeria. Several attempts have been made to use earthquakes as a proxy for mapping the geometry of plate boundary, for instance in the westernmost Mediterranean region (Fadil et al., 2006), without providing unequivocal evidence. This is even a more critical challenge when the known seismicity is moderate and diffuse, as in the Annaba region (Figures 3 and 4). Furthermore, no important historical events were reported in this area (Harbi et al., 2004; Harbi, 2006; Figure 3). During the last centuries, the intensities of events were generally not greater than VII (Yelles et al., 2006, and references therein). The largest event reported, of intensity X, occurred in 1722 north of Seraidi (Harbi, 2006; Figure 3 and Table 1) but remains uncertain as damages reported by historical documents are limited. Furthermore, most events located offshore (Figure 3) suffer possible large uncertainties.

From 1910 to today, i.e. during the instrumental period, the region of Annaba did not experience any important seismic activity as the largest magnitudes (local, $\mathrm{M}_{\mathrm{L}}$ ) of events reported were less than 4.3 (Figure 4). Most of the seismic activity in the region appears to be concentrated onshore, with small events located offshore (Figure 4). This led to conclude that the Annaba region and possibly the whole eastern margin are relatively quiet in comparison to other parts of the Algerian margin. The only major event to be mentioned in the eastern Algerian margin is the August 21-22, 1856, Djidjelli double earthquake (Intensity $X$ ) which triggered a tsunami in the Western Mediterranean Sea (Figure 4 and Table 1; Hee, 1950; Roussel, 1973).

On land, seismic activity appears slightly more intense and diffuse than in the western part of Algeria, but with lower magnitudes. Events are often located close to distinct geological units of the eastern region, such as the suture between the Internal and External Zones (Figures 2 
and 4). In recent times, several moderate magnitude events happened (Table 1), as the October 27, 1985, M 6.0 Constantine, the November 10, 2000, Mw 5.4 Beni Ouartilane, or the March 20, 2006, Mw 5.3 Laalam earthquakes (Beldjoudi et al., in press). Differences in the seismicity rates between the eastern and the western parts of Algeria from the 19012004 earthquake data base (e.g. Serpelloni et al., 2007) do not correlate with the progressive W-E shortening rate increase inferred from geological or geodetic models (Calais et al., 2003). It is thus obvious that the extent of the seismicity catalogue is too short to be considered as representative of the long term deformation for such a slowly deforming region. Therefore, no straightforward conclusion on the seismogenic potential of eastern Algeria can be drawn from this data set alone.

\section{Methods}

This work is based on data collected during the Maradja2/Samra cruise (2005) onboard the research vessel Le Suroît (Ifremer). Different types of high high-resolution data have been recorded by instruments on board. The 3D bathymetry and reflectivity data were obtained using a Kongsberg EM300 Simrad multibeam echosounder, and a 50 m resolution digital elevation model has been derived using the seafloor mapping software CARAIBES (CARtography Adapted to Imagery and BathymEtry of Sonars and multibeam echosounders) which is the Ifremer system for processing multibeam echosounders and sidescan sonars data. Seismic reflection data (Fig. 5) were usually recorded using a 24-channel (channel length $12.5 \mathrm{~m}, 4200 \mathrm{~km}$ of lines) streamer. Few lines (Mdj2-42, 43, 44, 47, Fig. 5) were shot using a 2D high high-resolution (HR) 72 channel (channel length $6.25 \mathrm{~m}, 120 \mathrm{~km}$ of lines) streamer. The source array was made of 2 GI-Guns of 105/105 in.3 and 45/45 in.3 shot at 140 bars, except for the HR streamer, for which we have used $2 \mathrm{Gl}$ of 45/45 in. 3 each and 3 mini-Gl of 35/35 in.3 each at 140 bars. Depth of sources and streamers have been fixed at 7-8 $\mathrm{m}$ and $1.5 \mathrm{~m}$ for 24-channel and 72-channel seismics, respectively. The SEGY format files recorded onboard were processed with Seismic Unix (SU) software (Center of Wave Phenomena, Colorado schools of Mines) for stack and migration. From shot spacing and time intervals chosen in the 24-channel seismics, we got a fold of 4 for stacking. In addition to seismic investigation, we used a Chirp sonar (about $4000 \mathrm{~km}$ of profiles). The hullmounted TRITON-ELICS Chirp profiler of the N/O Le Suroît emits frequencies between 1.8 and $5.3 \mathrm{kHz}$. Signal radiated by the sonar is a linear frequency modulation of $10-80 \mathrm{~ms}$ length, and signal received on the transducer is a time series of reflected waves in the sediment. Data vertical accuracy is about $40 \mathrm{~cm}$; we apply corrections for ship motions and water speed, allowing for a vertical resolution estimated at less than $1 \mathrm{~m}$. During the Maradja2/Samra cruise, acquisition was made by Delph 2.3 software, with a shot interval of 4 $\mathrm{s}$, a recording length of 250 or $500 \mathrm{~ms}$, and a Chirp length of $50 \mathrm{~ms}$. The Chirp data have proved to be especially well suited for identifying sub-surface scarps of a few meters high related so single events (see e.g. recent results in the sea of Marmara, in Armijo et al., 2005).

\section{Results}

\subsection{Morphology: scarps, ridges, canyons, scars}

For the first time, a detailed morphological view of the area off Skikda and Annaba has been obtained (Fig. 3 and Fig. 5). Although a full coverage is limited to the continental slope and the deep basin, we identify sharp contrasts in the extent of the continental shelf and in the shape of the slope. We outline four morphological sectors with distinct characters from West to East (Fig. 3): (1) Off the Skikda bay (from Collo Massif to Cap de Fer), the shelf is relatively narrow (about $20 \mathrm{~km}$ ), and the middle to lower slope, striking roughly $\mathrm{W}-\mathrm{E}$, is 
deeply incised by numerous canyons depicting several tributaries upstream and wide valleys at their outlets; (2) Off Cap de Fer, the continental shelf is virtually absent, and the incision of the slope appears characterized by narrow and straight gullies forming a radial pattern from $7^{\circ} 10^{\prime} \mathrm{E}$ to $7^{\circ} 28^{\prime} \mathrm{E}$, following the rounded shape of the slope (Fig. 3) of structural origin (plutonic body, Fig. 2); (3) East of Cap de Fer, from $7^{\circ} 28^{\prime} E$ to $7^{\circ} 40^{\prime} E$, there is no more regular continental shelf, and five large canyons, closely spaced, incise the slope, connecting directly the shore to the deep basin, and merging downslope; (4) Finally, east of $7^{\circ} 40^{\prime}$, the shelf is wide (up to $45 \mathrm{~km}$ ), gently and regularly dipping (about $7^{\circ}$ ), and presents a $\sim \mathrm{N} 60^{\circ} \mathrm{E}$ linear slope break at isobath $\sim 1300 \mathrm{~m}$, approximately parallel to the foot of the slope, which is only locally incised by narrow and widely spaced gullies, with no direct connection to the drainage network onshore (Fig. 3). Upstream of the gullies or canyon heads, slide scars are clearly observed.

In the deep basin, a sharp contrast in the morphology also exists west and east of Meridian $7^{\circ} 35^{\prime} \mathrm{E}$ (Fig. 3): the western part depicts a series of sub-parallel, swaying (at short wavelength), $\sim \mathrm{W}-\mathrm{E}$ oriented topographic highs and lows, generally wide (except off Collo city), which are often disappearing in the prolongation of the main outlets of the canyons (Fig. 3). The eastern part of the deep basin depicts several long, slightly curved topographic ridges, sub-parallel or slightly oblique to the foot of the margin and widely overlapping each other, separated by flat surfaces (Fig. 3 and Fig. 5). Typically, the ridges have lengths ranging between 15 and $30 \mathrm{~km}$ (Fig. 5), heights ranging from $\sim 30 \mathrm{~m}$ to $\sim 300 \mathrm{~m}$ above the basin floor (Fig. 5 and Table 2), and mean azimuths from $\mathrm{W}-\mathrm{E}$ to $\mathrm{N} 50^{\circ} \mathrm{E}$, whereas flat areas limited by the foot of the slope and the ridges have rhomboidal shapes and maximum widths of $~ 10-15 \mathrm{~km}$. The surface expression of one of the main ridges is abruptly ending at the place where the 5 main canyons merge in the deep basin, near Meridian $7^{\circ} 35^{\prime} \mathrm{E}$ (Fig. 5): this suggests that erosional processes linked to canyon activity overcome the processes responsible for the ridge formation and development. We will further develop this aspect after investigating the structures observed below the seafloor.

\subsection{Deep structures: asymmetrical folds}

The multichannel seismics deployed during Maradja2/Samra cruises penetrates down to $1500 \mathrm{~ms}$ below the seafloor, which appears generally not enough to image the base of the Messinian salt layer, present ubiquitously in the Mediterranean (Réhault et al., 1984). However, the resolution is higher compared with seismic data available in the western Algerian margin ([Déverchère et al., 2005] and Domzig et al., 2006 A. Domzig, C. Le Roy, K. Yelles, J. Déverchère, J.-P. Bouillin, R. Bracène, B. Mercier de Lépinay, P. Le Roy, E. Calais, A. Kherroubi, V. Gaullier, B. Savoye and H. Pauc, Searching for the Africa-Eurasia Miocene boundary offshore Western Algeria (MARADJA'03 Cruise), C.R. Geosci. 338 (2006), pp. 80-91. Article | PDF (910 K) | View Record in Scopus | Cited By in Scopus (18)[Domzig et al., 2006]) or in the whole margin from oil industry lines ([Cope, 2003] and [Mauffret, 2007]).

We present and interpret here two representative high-resolution (72 channel) seismic sections crossing the shelf, the slope and the ridges and scarps in the deeper basin (Plate I and Plate II, with enlargements in Fig. 6). Section 43 (Plate I) strikes perpendicular to the main structural directions (slope break and ridge axes), whereas Section 44 (Plate II) is oblique of about $\sim 30^{\circ}$ and cuts the eastern canyon on the slope off Cap de Fer - Annaba (Fig. 3 and Fig. 5). For simplicity, we use hereafter a mean velocity of $2 \mathrm{~km} / \mathrm{s}$ in order to estimate the thickness of the upper sedimentary layers (e.g. Réhault et al., 1984). A thick ( $600 \mathrm{~ms}$ twtt, $\sim 600 \mathrm{~m}$ ) pile of well-stratified sediments is covering an irregular, truncated surface from the upper shelf down to the middle slope. This unit (called PQ hereafter) is generally undisturbed except locally, where 3 sets of steep faults with limited offsets coincide with a broad folding of the pile and slight slope changes (Arrows 1, 2, 3, Plate I). In the lower slope, the PQ unit, although still stratified, becomes more acoustically transparent, and is thinner. Furthermore, it is locally fully eroded by the large eastern canyon (Section 44, Plate 
II). Below the truncature, the acoustic basement above the first multiple is clearly folded, depicting southward-dipping flanks in the middle and lower slopes (Plate I).

From the foot of the margin toward the deep basin, the PQ Unit appears thicker ( $800 \mathrm{~ms}$ twtt, $\sim 800 \mathrm{~m}$ ) and is underlain conformably by a continuous sedimentary unit, of high amplitude and good continuity (called hereafter UE Unit). From the overall facies distribution in the Mediterranean (e.g. Réhault et al., 1984 J.P. Réhault, G. Boillot and A. Mauffret, The western Mediterranean Basin geological evolution, Mar. Geol. 55 (1984), pp. 447-477. Abstract | PDF (2381 K) | View Record in Scopus | Cited By in Scopus (119)Réhault et al., 1984), we will assume that the Upper Unit (PQ) is the Plio-Quaternary sedimentary layer, whereas the UE Unit represents the Upper Evaporite sequence of the Messinian event. On a distance of about $10 \mathrm{~km}$ from the foot of the margin, both sedimentary units (PQ and UE) show a similar geometry at a broad scale: they form a large, asymmetrical anticline, with a gently dipping, relatively flat and longer $(\sim 8 \mathrm{~km})$ backlimb landward, and a steeper and shorter flank seaward (Fig. 6). Further north, only the UE Unit and the lower part of the PQ Unit show folding, at much shorter wavelength, with a similar asymmetrical pattern. As a whole, both UE and $\mathrm{PQ}$ units remain nearly conformable and with a similar thickness along both lines, except the Upper part of the $P Q$ Unit in the limbs of the main folds (above Reflector R, Fig. 6): there, onlaps appear on the backlimbs and forelimbs of the folds, resulting into the formation of growth strata and the birth of young, uplifted basins $\sim 10 \mathrm{~km}$ wide (Plate I and Plate II, Fig. 5 and Fig. 6). The thickness of sediments above the R reflector in the deepest part of the basin can be estimated to $\sim 300 \mathrm{~m}$ and $\sim 450 \mathrm{~m}$ on Lines 43 (Plate I) and 44 (Plate II), respectively. Several chaotic bodies of large extent are interbedded inside the main depocentre of the backlimb of Fold $A$ and thicken towards the foot of the slope (Line 44, Plate II and Fig. 6B), revealing the occurrence of large sedimentary instabilities.

We have drawn on both lines (43 and 44, Plate I and Plate II) the main faults deduced from strata offsets on seismic lines: first, clear sub-vertical fractures with nearly no offsets are observed at the hinge of the folds; second, a set of tenuous faults is located ahead the forelimb of the main folds, with limited offsets, and are prolonged at the surface by morphological scarps (A and B on Plate I and Plate II). Resolution of 72-channel seismics prevents us from precisely following the fault traces through the sedimentary layers.

\subsection{Shallow structures: faulted folds and single or cumulative scarps}

The high high-resolution Chirp profiles offer the opportunity to accurately describe the recent depositional pattern on the perched basins downslope and on the scarps identified (Fig. 7). At the northern ends of Lines Mdj2c-43 and -44 (Fig. 5), we clearly observe the prominent ridges formed above Scarps $B$ and $A$, respectively, and the ongoing deposition of growth strata on the backlimb of the folds (Fig. 7B). Whereas Line 44 depicts a tilting of strata up to the crest of the bulge and numerous chaotic bodies downslope, Line 43 evidences a continuous folding with tilted strata deposited only in the deeper part of the backlimb. The maximum heights of the bulges above the basin floors are $195 \mathrm{~m}$ and $300 \mathrm{~m}$ toward the hinterland ( $\mathrm{H} 1$ in Table 2) and $112 \mathrm{~m}$ and $67 \mathrm{~m}$ toward the foreland ( $\mathrm{H} 2$ in Table 2) for Scarps B and A, respectively. Scarp D, located further oceanward (Fig. 7A), depicts much smaller vertical heights (45 $\mathrm{m}$ and $15 \mathrm{~m}$ toward the hinterland and the foreland respectively, Fig. 8 and Table 2). We also note that heights of scarps tend to decrease from the centre to the tips of segments, generally in a progressive way, except for the western tip of Scarp A, located at the vicinity of the junction of canyons (Fig. 5 and Fig. 7A).

Another clear characteristics of Scarps A, B and D on Chirp lines is the existence of abrupt lateral changes in the acoustic properties of shallow sediments at few kilometers from the bottom of the forelimbs of folds (Fig. 7 and Fig. 8): on Line 43 (Fig. 7B, Scarp B), a set of close faults (B) shifts of $\sim 1 \mathrm{~m}$ (Table 2) a domain of flat, sub-parallel reflectors to the NW from a domain of disturbed, tilted sediments, $\sim 2 \mathrm{~km}$ wide, at the foot of the fold. On Line 44 (Fig. 7B), Scarp A shifts of $\sim 1.5 \mathrm{~m}$ (Table 2) several folded reflectors, and Scarp B limits 
chaotic bodies from layered units folded near this contact. Finally, Scarp D (Fig. 8) represents a faulted hinge of an asymmetrical fold of much smaller magnitude compared to Scarps A and B.

\section{Discussion}

Active, fault-related folds received recently an increasing interest through multidisciplinary studies (Dolan and Avouac, 2007 and references therein) because, among other reasons, they may help to decipher the finite deformation and the earthquake cycles on underlying faults. Fig. 9 and Fig. 10 summarize the spatial distribution and tectonic style of the main fold scarps identified in perspective and map views, respectively. They depict thrust faulting striking roughly E-W, with no apparent strike-slip component. Apart from Scarps A, B, C, and $D$ already discussed, we map two other scarps: Scarp $E$ is trending in the western extension of Scarp A, and may represent the same fault system, on the other side of the junction of canyons; Scarp F is observed on the upper slope, close to the slope break, with an apparent normal throw, and is rooted in the acoustic basement (Plate I), suggesting a genetic link with the fold $B$. In the following, we discuss the finite, cumulative and possible coseismic deformations observed on the folds of the Annaba offshore region, focusing on similarities or differences with the Algiers area, where recent and active deformation submarine systems have been recently described ([Déverchère et al., 2005] and [Yelles et al., submitted for publication]), and argue about implications for seismic hazards and long-term deformation of the Algerian margin.

\subsection{Folds: tectonic- or salt-related?}

Salt tectonics is known to trigger important displacements in the sedimentary successions, during or after sedimentation. This is especially true in the Mediterranean, where a relatively thick salt sequence has deposited during Late Miocene (see e.g. [Ryan and Hsu, 1973] and [Gaullier and Vendeville, 2005], and references therein). A major role of the Messinian salt in the main folding observed at the foot of the margin (Fig. 6) is unlikely for several reasons: (1) the surface effect of this folding is very clear, producing long ridges several tens of kilometers long, which is generally not the case for gravity-induced structures (Gaullier, 1993 Gaullier, V., 1993. Diapirisme salifère et dynamique sédimentaire dans le bassin Liguro- Provençal: données sismiques et modèles analogiques. Thèse de doctorat, Université Pierre et Marie Curie, Paris. p. 327.Gaullier, 1993); (2) the folding is strongly asymmetrical, of large wavelength, with a relatively long, flat backlimb tilted towards the continent, which is not the case for a salt-driven dome, even close to the foot of margins (e.g. Gaullier and Bellaiche, 1996); and (3) growth strata on the backlimb of the folds are clearly well developed in the Upper layer of $\mathrm{PQ}$ sediments, whereas short wavelength salt domes seaward appear to produce progressively decreasing effects on $\mathrm{PQ}$ deposition from bottom to the middle of the $\mathrm{PQ}$ layer (Plate I and Plate II). Furthermore, deeper-penetration lines near the foot of the margin in the same area (for instance, ALE10 shown in Mauffret, 2007) or in other areas off Algeria ([Déverchère et al., 2005] and [Yelles et al., submitted for publication]) suggest that deformation is rooted below the salt layer, i.e. implying a crustal deformation. We thus infer that salt-driven tectonics plays a role only for the anticlines that appear seaward of both profiles 43 and 44 (Plate I and Plate II), from the wavelength (much shorter) and the more symmetrical shape of the domes, which is typical from other salt doming observed elsewhere in the Mediterranean (e.g., [Gaullier, 1993] and [Gaullier and Bellaiche, 1996]). In order not to overestimate the role of tectonic forces, we consider here that tectonics sensu stricto is only responsible for the origin and evolution of the first large, asymmetrical folds observed near the foot of the slope (Fig. 7A). These fault-related folds share some similarities with the fold evidenced in the Boumerdes area off NE Algiers (Déverchère et al., 2005) regarding their length and position relative to the foot of the slope 
(outer limit of a piggy-back basin with typical growth strata). It is beyond the scope of this paper to determine whether the folds at the foot of the Annaba slope result from fault-tip folding (i.e., folding at the tip of a blind thrust) or fault-bend folding ([Suppe, 1983] and [Burbank and Anderson, 2001]), because we lack enough geometrical (at depth) and age constraints, and because the choice of a kinematic model is not straightforward even when the geometry of growth strata is well known (Dolan and Avouac, 2007, and references therein). However, we may infer from their general asymmetrical shape (Plate I and Plate II) that the folds are driven by faults of unknown geometry at depth, and that they are possibly similar to structures observed in fault-propagation folding models from limb folding and dips (Burbank and Anderson, 2001).

\subsection{Fault segmentation and seismic potential}

The observation of Chirp profiles located off Annaba shows for the first time morphological scarps of $\sim 1-2 \mathrm{~m}$ high on the seafloor $(\mathrm{H} 3$, Table 2). The occurrence of submarine scarps may indicate coseismic ruptures if they appear consistent in length (L) and mean single displacement (D), as in the Marmara Sea (Armijo et al., 2005 R. Armijo, N. Pondard, B. Meyer, B. Mercier de Lépinay, G. Uçarkus and Marmarascarps Cruise Party, Submarine fault scarps in the Sea of Marmara pull-apart (North Anatolian Fault): implications for seismic hazard in Istanbul, Geochem. Geophys. Geosyst. 6 (2005), p. Q06009 10.1029/2004GC000896. Full Text via CrossRefArmijo et al., 2005) for instance. If we assume that the scarps represent surface slip of fault planes, that the displacement observed has occurred during a single event, and that the lengths of ridges at the surface (ranging from 15 to $30 \mathrm{~km}$, Fig. 10) represent rupture lengths, the potential magnitude of an associated earthquake can be inferred from D-L regressions (Wells and Coppersmith, 1994). However, it is necessary to recall that: (1) part of the surface expression of fault activity may be concealed by sedimentation, especially at tips of overlapping segments, where cumulative displacements are less: this is indeed what is suggested by the along-strike evolution of scar heights, at least for the B and D segments (see $\mathrm{H} 1$ evolution, Table 2); (2) surface slip is only a fraction of actual slip at depth, averaging $\sim 40 \%$ for moderate-size reverse earthquakes (Manighetti et al., 2006); and (3) fault rupture of $M>6$ earthquakes often concerns several adjacent fault segments or cracks, inducing large along-strike-slip variability and slip saturation ([Rubin, 1995] and [Manighetti et al., 2005]). If we hypothesize here that close segments $A(\sim 30 \mathrm{~km}), B(\sim 30 \mathrm{~km})$, and $C(\sim 20 \mathrm{~km})$ may break during a single large event, the scaling relations between surface displacement and length (Manighetti et al., 2006) indicate relatively mature fault segments and yield a consistent seismic moment Mo of 1-2 $\times$ $1020 \mathrm{Nm}$ and a magnitude Mw of $\sim 7.5$ (Wells and Coppersmith, 1994), i.e. larger than the 2003 Boumerdes Mw 6.8 earthquake (Delouis et al., 2004). This value may be even higher if Scarp E (Fig. 9 and Fig. 10) is also considered. Although these estimates are speculative, they again strengthen the idea that the time interval of the seismicity catalogue is too short compared to the recurrence time for large earthquakes in such slowly deforming areas (Serpelloni et al., 2007). This therefore leads us to conclude that the occurrence of large earthquakes in the Annaba region cannot be ruled out. Whether or not the large scale mass movements revealed by the chaotic bodies found within the Plio-Quaternary sequence near the foot of the margin (Fig. 6B) have been triggered by large earthquakes is unclear. In any case, these thick deposits (about $0.1 \mathrm{~s}$ twtt) mean that tsunamic hazard has to be considered here and would have certainly an important impact on neighboring coasts of Africa and Europe.

\subsection{Timing of folding and faulting}

The limit between UE and PQ units can be dated at $\sim 5.3 \mathrm{Ma}$, as it marks the end of the Messinian Salinity Crisis sensu stricto (e.g., McKenzie, 1999). There is no precise time constraints on the age of deposition in the deep Algerian basin, owing to the lack of deep drilling (Cope, 2003 M.J. Cope, Algerian licensing round may offer opportunity for exploration 
plays in deep offshore frontier, First Break 21 (2003), pp. 37-42. View Record in Scopus | Cited By in Scopus (5)Cope, 2003). Furthermore, the seismic facies changes observed in the Plio-Quaternary layer does not provide reliable information, because there is no sharp seismic reflector inside this unit able to give a time reference (see e.g. Réhault et al., 1984), and because the acoustic properties (change from a high- to a low-amplitude facies from top to bottom) are not easy to correlate from one place to another in the Mediterranean, depending on the seismic tools used and the parameters of acquisition. However, we may attempt to extrapolate the mean Upper Quaternary sedimentation rates found at the foot of the slope in other regions of the Algerian margin (West of Tenes and Algiers), i.e. about 0.5 $\mathrm{mm} / \mathrm{yr}$ ([Giresse et al., 2005] and [Giresse and Pauc, in press]).

Using this depositional rate value and the reflector R (Fig. 4, Fig. 5 and Fig. 6) as the marker of the onset of the main tectonic deformation (wedge-shape of strata deposited above, see Section 4.2), we estimate an age of $R$ reflector of $0.60 \pm 0.06 \mathrm{Ma}$ and $0.90 \pm 0.09$ $\mathrm{Ma}$ in the deeper parts of Lines 43 (fold B) and 44 (fold A) respectively, taking into account uncertainties on Quaternary seismic velocity $(2.0 \pm 0.2 \mathrm{~km} / \mathrm{s})$. This results suggests again that deformation is propagating toward the deep basin. Furthermore, if we assume that the maximum heights on B and A scarps ( $\sim 200 \mathrm{~m}$ and $\sim 300 \mathrm{~m}$ respectively, Table 2$)$ reflect the cumulative reverse heaves of faulting at depth, we obtain a minimum estimate of the reverse heave rates of $0.33 \pm 0.04 \mathrm{~mm} / \mathrm{yr}$, which is close to the deposition rate assumed. This a posteriori result suggests that a mean deposition rate of $0.5 \mathrm{~mm} / \mathrm{yr}$ is conceivable, provided that tectonic vertical rate should remain close to this value in order to allow cumulative scarps to appear at the seafloor for young fault-propagation folding (see e.g. [Allmendinger, 1998] and [Domzig, 2006]).

Using the age of $0.9 \pm 0.1 \mathrm{Ma}$ as a hypothetical onset of folding, we estimate the shortening rate across the fold: dividing the $\mathrm{R}$ length by the present-day horizontal distance across the fold $(\sim 10 \mathrm{~km})$, we obtain a minimal shortening factor of $\sim 8 \%$ on both profiles used. Hence we get a horizontal shortening rate of $0.9 \pm 0.1 \mathrm{~mm} / \mathrm{yr}$ for each fold over this time period. If we assume that the folding is entirely driven at depth by a single fault, and if we consider a mean dip for the fault of $47 \pm 7^{\circ}$, by analogy with the fault activated during the 2003 Boumerdes earthquake (e.g. Delouis et al., 2004), we obtain a slip rate of $1.3 \pm 0.4$ $\mathrm{mm} / \mathrm{yr}$. Although this value must be taken with caution, considering the assumptions made on the sedimentation rates and the large uncertainties on geometry of the fold system at depth and on its links to faulting, it is interesting to remark that the mean horizontal rate of $0.9 \mathrm{~mm} / \mathrm{yr}$ on the fault-related folds found here represents a significant part of the $\sim 1.5$ $\mathrm{mm} / \mathrm{yr}$ shortening rate predicted offshore by Stich et al. (2006) from completely independent data (GPS modelling). This fault-related folding could therefore accommodate much of the present-day submarine shortening rate between the European and African plates. It is also worth to note that this faulting is apparently active at a faster rate (about 3 times) and more recently $(\sim 0.9$ and $\sim 0.6 \mathrm{Ma}$ instead of $\sim 1.2 \mathrm{Ma})$ than the similar faulting observed at the foot of the margin NW of Algiers (Yelles et al., submitted for publication). Finally, the comparison of heights of Scarps A, B, and D (Fig. 5, Fig. 7 and Fig. 8; Table 2) suggests that Scarp $D$ is the youngest scarp among those described here and that deformation is therefore propagating toward the deep basin.

\subsection{Mechanisms of subduction inception and tectonic style}

nitiation of subduction takes place preferentially at pre-existing weakness zones or at prestressed regions of the lithosphere which allow localization of deformation, leading most authors to underline the importance of the initial tectonic state (topography, asymmetry, buoyancy and density differences, see e.g. Gurnis et al., 2004). Therefore passive margins

are good potential locations for such a process to occur (e.g. [Cloetingh et al., 1982], [Faccenna et al., 1999] and [Leroy et al., 2004]; and references therein). Two main forces must be overcome to allow subduction to develop: elastic plate flexure (bending stress) and 
frictional resistance across a pre-existing fault (McKenzie, 1977). In our case study, although the slow convergence rate is not favoring a spontaneous subduction nucleation at the continent-ocean transition ([Faccenna et al., 1999] and [Stern, 2004]), the sediment loading acting on a young lithosphere may provide an effective mechanism to enhance this process (Cloetingh et al., 1982). Similar case studies of Plio-Quaternary inversion of a former backarc basin can be found in the Japan sea (e.g. Tamaki and Honza, 1985) and in the southern Tyrrhenian sea (Billi et al., 2007). Both the Tyrrhenian and the Algerian margins could illustrate the first steps of an induced subduction by polarity reversal of slabs ([Stern, 2004] and [Gurnis et al., 2004]), probably enhanced by the large body forces in the hinterlands arising from the preceding collision of Kabylian and Peloritan blocks of the AlKaPeCA terrane ([Bouillin, 1986] and [Michard et al., 2006]). Although each case remains singular, we note that these 3 areas all share a pattern of continentward-dipping faults developing near the ocean-continent transition, suggesting that these active structures either are neo-formed or re-activate pre-existing zones of weakness of the previous margin such as serpentinized peridotites at the transition to the ocean or a detachment fault in the thinned continental crust (Masson et al., 1994). Whatever the case, we note that there is apparently no strong influence of the tectonic style which has shaped the Algerian margin during Miocene before the collision, which is assumed to be dominantly transcurrent in eastern Algeria and extensional in Central Algeria (Bouillin et al., 1986). Onshore, the recent and present-day strain field in eastern Algeria (Tell and Atlas) appears to be characterized by dextral wrench tectonics along NW-SE structures ([Piqué et al., 1998], Frizon de Lamotte et al., 2000 D. Frizon de Lamotte, B. Saint Bezar, R. Bracène and E. Mercier, The two main steps of the Atlas building and geodynamics of the western Mediterranean, Tectonics 19 (4) (2000), pp. 740-761.[Frizon de Lamotte et al., 2000] and [Serpelloni et al., 2007]), suggesting strain partitioning between land and sea. A more thorough and quantitative analysis of the margin and land reactivation will require additional data at deeper levels of the lithosphere along the Algerian margin.

\section{Concluding remarks}

This study reveals for the first time the development of young, active fault-related folds at the foot of the Algerian margin off the Annaba region. We interpret this pattern of recent (less than $1 \mathrm{Ma}$ ) and active faulting identified as a recent increase of the tectonic activity from west to east along the Algerian margin, which tends to focus at the northward limit of the Internal Zones (i.e. the oceanic-continental transition), as found in many places along northern Africa (e.g. Domzig, 2006). Indeed, the area offshore Algiers-Annaba may be the place where the recent convergence between the African and European plates can be better accounted for since the closure of the Tethyan ocean and the collision of the Internal Zones with the African passive margin by $15 \mathrm{Ma}$. This pattern may reveal the inception of a subduction, as suggested since long (e.g., Auzende et al., 1975 J.-M. Auzende, J. Bonnin and J.L. Olivet, La marge nord-africaine considérée comme marge active, Bull. Soc. Géol. Fr. 17 (7) (1975), pp. 486-495.Auzende et al., 1975). The point worth to underline here is that the active faults identified in this study are similar in length (few tens of kilometers), tectonic style (reverse faulting), position (vicinity of the foot slope of the margin), and geometry (south-dipping segments) from those found in Central Algeria, although our study area is located close to the collapsed Miocene fold-and-thrust belt between Sicily and Tunisia ([Auzende et al., 1974], [Tricart et al., 1994] and [Mascle et al., 2001]). Recent findings in the south-central Mediterranean ([Goes et al., 2004] and [Billi et al., 2007]) suggest a similar pattern of tectonic reorganization and of incipient subduction at the northern limit of the Maghrebian orogenic wedge, with the development of a very young (500-700 ka) south-dipping thrust system. An explanation for the youthfulness of this process may be found in a progressive change of the body forces through time: after the collision and collage of the Internal Zones in Miocene times, the relative convergence between Europe and Africa could no more be accommodated on land, thus favoring a transfer of stress at the boundary between 
continental and oceanic crust, i.e. at the foot of the margin (e.g. Mart et al., 2005). The use of deep seismic tools for fault geometry at depth and the mapping and dating of turbidites in the deepest part of the basin may help in the future to further mitigate the seismic hazards of this fault system and to clarify the mechanisms of subduction inception.

\section{Acknowledgments}

We thank the crews and captains of the R/V Le Suroît for efficient support during the Maradja 2003 and Maradja2/Samra 2005 cruises. We are grateful to anonymous reviewers for their valuable comments. This research is funded by the ESF-EUROMARGINS 01-LEC-EMA22F 'Westmed' Project through 'GDR Marges', the Ifremer project PJE0203 'Risques de glissements et d'avalanches sous-marines, turbidités et risques sismiques', the French Programme ACl (Action Concertée Incitative) 'Algérie' 2003-2006, the ANR (Agence Nationale de la Recherche) DANACOR Project, and the French-Algerian Cooperation Project CMEP-Tassili 2004-2007 No. 041MDU619. This is Contribution No. 1084 of the IUEM, European Institute for Marine Studies (Brest, France). 


\section{References}

Allmendinger, R.W., 1998. Inverse and forward numerical modeling of trishear faultpropagation folds, Tectonics, 7, 640-656.

Ambraseys, N., and Vogt, J., 1988. Material for the investigation of the seismicity of the region of Algiers, Eur. Earthq. Eng. 3, 16-29.

Armijo, R., Pondard, N., Meyer, B., Mercier de Lépinay, B., Uçarkus, G., and the Marmarascarps Cruise Party, 2005. Submarine fault scarps in the Sea of Marmara pull-apart (North Anatolian Fault): implications for seismic hazard in Istanbul, Geochem. Geophys. Geosyst., 6, Q06009, doi:10.1029/2004GC000896.

Augier, R., Jolivet, L., and Robin, C., 2005. Late orogenic doming in the eastern Betic Cordilleras: final exhumation of the Nevado-Filabride complex and its relation to basin genesis, Tectonics, 24, TC4003, doi:10.1029/2004TC001687.

Auzende, J-M., Bonnin, J., and Olivet, J.L., 1973. The origin of the western Mediterranean Basin, J. Geol. Soc. London, 129, 607-620.

Auzende, J.M., Bonnin, J., and Olivet, J.L., 1974. Le détroit sardino-tunisien et la zone de fracture nord-tunisienne, Tectonophysics, 21, 357-374.

Auzende, J.-M., Bonnin, J., and Olivet, J.L., 1975. La marge nord-africaine considérée comme marge active, Bull. Soc. Géol. Fr., 17(7), 486-495.

Argus, D.F., Gordon, R.G., De Mets, C., and Stein, S., 1989. Closure of the Africa -Eurasia North America plate motions circuit and tectonic of the Gloria fault. J. Geophys. Res., 94, 5585- 5602.

Barrier, E., Chamot-Rooke, N., and Giordano, G., 2004. Geodynamical Map of the Mediterranean. Sheet 1: Tectonics and Kinematics, scale: 1:13 000 000. Commission for the Geological Map of the World (CGMW), Paris.

Beldjoudi, H., Guemache, M.A., Kherroubi, A., Semmane, F., Yelles- Chaouche, A. K., Djellit, H., Amrani, A., and Haned, A., 2007. The Laâlam (Béjaïa, North-East Algeria) moderate earthquake (Mw = 5.3) on March 20th, 2006. Pure and Applied Geophys., in press.

Billi, A., Presti, D., Faccenna, C., Neri, G., and B. Orecchio, 2007. Seismotectonics of the Nubia plate compressive margin in the south-Tyrrhenian region, Italy: clues for subduction inception, J. Geophys. Res., 112, B08302, doi:10.1029/2006JB004837.

Bouhadad, Y., Nour, A., Laouami, N. and Belhai, D., 2003, The Beni-Ourtilane-Tachouaft fault and Seismotectonic aspects of the Babors region (NE of Algeria), J. Seismol., 7, 79-88.

Bouillin, J-P., 1986. Le bassin maghrébin: une ancienne limite entre l'Europe et l'Afrique à l'Ouest des Alpes, Bull. Soc. Géol. Fr., 8(4), 547-558.

Bouillin, J-P., Durand-Delga, M., and Olivier, P., 1986. Betic-Rifian and Tyrrhenian Arcs: Distinctive features, genesis, and development stages, in: F.C.Wezel (Ed.), The Origin of Arcs, Elsevier, pp. 281-304. 
Bounif, A., Haessler, H., and Meghraoui, M., 1987, The Constantine (Northeast-Algeria) earthquake of October 27, 1985: surface ruptures and aftershocks study, Earth Planet. Sci. Lett., 85, 451-460.

Buforn, E., Sanz de Galdeano, C. , Udias, A., 1995. Seismotectonics of the IberoMaghrebian region, Tectonophysics 248, 247-261.

Burbank, D., and Anderson, R., 2001. Tectonic Geomorphology, 274 pp., Blackwell Sci., Malden, Mass., USA.

Calais, E., DeMets, C., Nocquet, J.M., 2003. Evidence for a post-3.16 Ma change in NubiaEurasia plate motion, Earth and Planetary Science Letters, 216, 81-92, doi:10.1016/S0012$821 \times(03) 00482-5$.

Cloetingh, S.A.P.L., Wortel, M.J.R., and Vlaar, N.J., 1982. Evolution of passive continental margins and initiation of subduction zones, Nature, 297, 139-142.

Comas, M.C., Platt, J.P., Soto, J.I., and Watts, A.B., 1999. The origin and tectonic history of the Alboran basin: insights from Leg 161 results, in R. Zahn, M.C. Comas, A. Klaus (Eds.) Proc. ODP, Scientific Results, 161 (44), 555-580.

Cope, M.J., 2003. Algerian licensing round may offer opportunity for exploration plays in deep offshore frontier, First Break, 21, 37-42.

Delouis, B., Vallée, M., Meghraoui, M., Calais, E., Maouche, S., Lammali, K., Mahsas, A., Briole, P., Benhamouda, F., and Yelles, K., 2004. Slip distribution of the 2003 BoumerdesZemmouri earthquake, Algeria, from teleseismic, GPS, and coastal uplift data, Geophys. Res. Lett., 31, L18607, doi:10.1029/2004GL020687.

Déverchère, J., Yelles, K., Domzig, A., Mercier de Lépinay, B., Bouillin, J.P., Gaullier, V., Bracène, R., Calais, E., Savoye, B., Kherroubi, A., Le Roy, P., Pauc, H., and Dan, G., 2005. Active thrust faulting offshore Boumerdes, Algeria and its relations to the $2003 \mathrm{Mw} 6.9$ earthquake. Geophys. Res. Letters, 32, L04311, doi:10.1029/ 2004GL021646.

Dolan, J. F., and Avouac, J.-P., 2007. Introduction to special section: Active Fault-Related Folding: Structural Evolution, Geomorphologic Expression, Paleoseismology, and Seismic Hazards, J. Geophys. Res., 112, B03S01, doi:10.1029/2007JB004952.

Domzig, A, 2006. Déformation active et récente, et structuration tectono-sédimentaire de la marge sous-marine algérienne, PhD thesis, Université de Brest (UBO), IUEM, Brest, France, $332 \mathrm{pp}$.

Domzig A., Le Roy C., Yelles K., Déverchère J., Bouillin J-P., Bracène R., Mercier de Lépinay B., Le Roy P., Calais E., Kherroubi A., Gaullier V., Savoye B., and Pauc H., 2005. Searching for the Africa-Eurasia Miocene boundary offshore Western Algeria (MARADJA'03 Cruise). C.R. Geoscience, 338, 80-91.

Durand-Delga, M., 1978. Alpine chains of the western Mediterranean Betic Cordilleras and Maghrebides, In: Lemoine, M. Ed.., Geological atlas of Alpine Europe and adjoining Alpine Areas. Elsevier, Amsterdam, pp. 163-225.

Faccenna, C., Giardini, D., Davy, P., and Argentieri, A., 1999. Initiation of subduction at Atlantic-type margins: Insights from laboratory experiments, J. Geophys. Res., 104(B2), 2749-2766. 
Faccenna, C., Piromallo, C., Crespo-Blanc, A., and Jolivet, L., 2004. Lateral slab deformation and the origin of the western Mediterranean arcs, Tectonics, 23, TC1012, doi:10.1029/2002TC001488.

Fadil, A., Vernant, P., McClusky, S., Reilinger, R., Gomez, F., Ben Sari, D., Mourabit, T., Feigl, K., and Barazangi, M., 2006. Active tectonics of the western Mediterranean: Geodetic evidence for rollback of a delaminated subcontinental lithospheric slab beneath the Rif Mountains, Morocco, 34(7), 529-532.

Farr, T.G., et al., 2007. The Shuttle Radar Topography Mission, Rev. Geophys., 45, RG2004, doi:10.1029/2005RG000183.

Frizon de Lamotte, D., Saint Bezar, B., Bracène, R., and Mercier, E., 2000. The two main steps of the Atlas building and geodynamics of the western Mediterranean, Tectonics, 19 (4), 740-761.

Gaullier, V., 1993. Diapirisme salifère et dynamique sédimentaire dans le bassin LiguroProvenc,al: données sismiques et modèles analogiques. Thèse de doctorat, Université Pierre et Marie Curie, Paris. p. 327.

Gaullier, V., and Bellaiche, G., 1996. Diapirisme liguro-provençal: les effets d'une topographie résiduelle sous le sel messinien. Apports de la modélisation analogique. C.R. Acad. Sc., Paris 332 (série Ila), 213-220.

Gaullier, V., and Vendeville, B., 2005. Salt tectonics driven by sediment progradation: Part II - Radial spreading of sedimentary lobes prograding above salt, AAPG Bull., 89(8), 10811089.

Giresse, P., Pauc, H., Savoye, B., Dan, G., Déverchère, J., Gaullier, V., and the Maradja scientific party, 2005. Sediment accumulation rates and gravity-induced processes evidenced offshore Algeria from coring results (Maradja cruise), Abstract, EGU Vienna, EGU05-A-07849.

Giresse et al., Sedimentary processes and origin of sediment gravity-flow deposits on the western Algerian margin during late Pleistocene and Holocene, Marine and Petroleum Geology, Thematic Set on New Insights on Slope Instabilities from Recent Studies within the French Margin Program GDR "Marges", Gaullier V. \& Vendeville B. (Eds.), 26(5), 695-710, doi:10.1016/j.marpetgeo.2008.03.011, 2009.

Goes, S., Giardini, D., Jenny, S., Hollenstein, C., Kahle, H. G., and Geiger, A., 2004. A recent tectonic reorganization in the south-central Mediterranean, Earth Planet. Sci. Lett., 226, 335-345.

Gurnis, M., Hall, C., and Lavier, L., 2004. Evolving force balance during incipient subduction, Geochem. Geophys. Geosyst., 5, Q07001, doi:10.1029/2003GC000681.

Harbi, A., Maouche, S., Ayadi, A., Benouar, D., Panza, G.F., and Benhallou, H., 2004. Seismicity and tectonic structures in the site of Algiers and its surroundings: A step towards microzonation, Pure and Appl. Geophys., 161, 949-967.

Harbi, A., 2006. Evaluation de l'Aléa Sismique en Algérie du Nord par la Modélisation de I'Input Sismique dans les Zones Urbaines et l'Etablissement d'un Catalogue, thèse, USTHB, Alger, 223 pp. 
Hee, A., 1950. Catalogue des séismes algériens de 1850 à 1911, Ann. Institut de Physique du Globe, Strasbourg, VI, 41-49.

Leroy, M., Dauteuil, O., and Cobbold, P.R., 2004. Incipient shortening of a passive margin : the mechanical roles of continental and oceanic lithospheres, Geophys. J. Int., 159, 400-411.

Manighetti, I., Campillo, M., Sammis, C., Mai, P. M., and King, G., 2005. Evidence for selfsimilar, triangular slip distributions on earthquakes: Implications for earthquake and fault mechanics, J. Geophys. Res., 110, B05302, doi:10.1029/2004JB003174.

Manighetti, I., Campillo, M., Bouley, S., and Cotton, F., 2006. Earthquake scaling, fault segmentation, and structural maturity, Earth Planet. Sci. Lett., doi:10.1016/ j.epsl.2006.11.004.

Mart, Y., Aharonov, E., Mulugeta, G., Ryan, W., Tentler, T., and Goren, L., 2005. Analogue modelling of the initiation of subduction, Geophys. J. Int., 160, 1081-1091.

Mascle, G.H., Tricart, P., Torelli, L., Bouillin, J.P., Rolfo, F., Lapierre, H., Monie, P., Depardon, S., Mascle, J., and Peis, D., 2001. Evolution of the Sardinia Channel (Western Mediterranean): New constraints from a diving survey on Cornacya Seamount off SE Sardinia, Marine Geology, 179, 179-202.

Masson, D.G., Cartwright, J.A., Pinheiro, L.M., Whitmarch, R.B., Beslier, M.O., and Roeser, $\mathrm{H} .$, 1994. Compressional deformation at the continent-ocean transition in the NE Atlantic, J. Geol. Soc. London, 151, 607-613.

Mauffret, A., 2007. The Northwestern (Maghreb) boundary of the Nubia (Africa) plate, Tectonophysics, 429 (1-2), 21-44. McKenzie, D.P., 1977. The initiation of trenches: A finite amplitude instability, in Island Arcs, Deep Sea Trenches and Back-Arc Basins, Maurice Ewing Ser., vol. 1, M. Talwani and W. C. Pitman (Eds.), pp. 57 -61, AGU, Washington, D. C.

McKenzie, J., 1999. From desert to deluge in the Mediterranean, Nature, 400, 613-614.

Michard, A., Negro, F., Saddiqi, O., Bouybaouene, M.L., Chalouan, A., Montigny, R., and Goffé, B., 2006. Pressure-temperature-time constraints on the Maghrebide mountain building: evidence from the Rif-Betic transect (Morocco, Spain), Algerian correlations, and geodynamic implications. C.R. Geoscience, 338, 92-114.

Morel, J.-L., Meghraoui, M., 1996. Gorringe-Alboran-Tell tectonic zone: A transpression system along the Africa-Eurasia plate boundary, Geology, 24, 755-758.

Peucat, J-J., Mahdjoub, Y., and Drareni, A., 1996. U-Pb and Rb-Sr geochronological evidence for late Hercynian tectonic and Alpine overthrusting in Kabylian metamorphic basement massifs (northeastern Algeria), Tectonophys., 258, 195-213.

Piqué, A., Aït Brahim, L., El Azzouzi, M., Maury, C., Bellon, H., Semroud, B., and Laville, E., 1998. Le poinçon Maghrébin: Contraintes structurales et géochimiques, C.R. Acad. Sci. Paris, 326, 576-581.

Réhault, J.P., Boillot, G., and Mauffret, A., 1984. The western Mediterranean Basin geological evolution, Marine Geology, 55, 447-477.

Roussel, J., 1973. Les zones actives et la fréquence des séismes en Algérie 1716-1970, Bull. Soc. Hist. Natur. Afrique du Nord. 64 (3), 2 pp. 11-227. 
Rubin, C.M., 1995. Systematic underestimation of earthquake magnitudes from large intracontinental reverse faults; historical ruptures break across segment boundaries, AAPG Bulletin, 39(12), 2505-2514.

Ryan, W. B. F., \& Hsu, K. I., 1973. Inital Report of the Deep Sea Drilling Project, Washington DC: US Government Printing Office, Vol. 13, 1447 pp.

Saadallah, A., and Caby, R., 1996. Alpine extensional detachment tectonics in the Grande Kabylie metamorphic core complex of the Maghrebides (northern Algeria), Tectonophys., 267, 257-273.

Stern, R.J., 2004. Subduction initiation: spontaneous and induced, Earth Planet. Sci. Lett., 226, 275-292.

Serpelloni, E., Vannucci, G., Pondrelli, S., Argnani, A., Casula, G., Anzidei, M., Baldi, P., and Gasperini, P., 2007. Kinematics of the western Africa-Eurasia plate boundary from focal mechanisms and GPS data, Geophys. J. Int., 169(3), 1180-1200, doi: 10.1111/j.1365246X.2007.03367.X.

Stich, D., Ammon, C. J., Morales, J., 2003. Moment tensor solutions for small and moderate earthquakes in the Ibero-Maghreb region, J. Geophys. Res., 108(B3), 2148, doi:10.1029/2002JB002057.

Stich, D., Serpelloni, E., F-L. Mancilla, J. Morales, 2006. Kinematics of the Iberia-Maghreb plate contact from seismic moment tensors and GPS observations, Tectonophysics, 426, 34, 295-317, doi:10.1016/j.tecto.2006.08.004.

Suppe, J., 1983. Geometry and kinematics of fault-bend folding, Am. J. Sci., 283(7), 684721.

Tamaki, K., and Honza, E., 1985. Incipient subduction and obduction along the eastern margin of the Japan Sea, Tectonophys., 119, 381-406.

Tricart, P., Torelli, L., Argnani, A., Rekhiss, F., Zitellini, N., 1994. Extensional collapse related to compressional uplift in the Alpine chain off northern Tunisia (Central Mediterranean), Tectonophysics, 238, 317-329.

Vila, J.-M., 1980. La chaîne alpine d'Algérie orientale et des confins algéro-tunisiens. Doctorate Dissertation, Univ. Paris VI, France, 665 pp.

Wells, D.L., and Coppersmith K.J., 1994. New empirical relationships among magnitude, rupture length, rupture width, rupture area, and surface displacement, Bull. Seism. Soc. Am., 84, 974-1002.

Wildi, W., 1983. La chaîne tello-rifaine (Algérie, Maroc, Tunisie): Structure, stratigraphie et évolution du Trias au Miocène, Rev. Géol. Dyn. Géogr. Phys., 24, 201-297.

Yelles, A.K., Boudiaf, A., Djellit, H., and Bracène, R., 2006. La tectonique active de la région nord-algérienne, C. R. Geoscience, 338 (2006) 126-139.

Yelles et al., Plio-Quaternary reactivation of the Neogene margin off NW Algiers, Algeria: the Khayr-Al-Din bank, Tectonophysics, Special Issue on "The geology of vertical movements of the lithosphere, Bertotti G., Teixell A., Frizon de Lamotte D., \& Charroud M., (Eds.), 475, 98116, doi:10.1016/j.tecto.2008.11.030. 
Zitellini, N., Rovere, M., Terrinha, P., Chierici, F., Matias, L. \& Bigsets Team, 2004. Neogene through Quaternary tectonic reactivation of SW Iberian passive margin, Pure and Appl. Geophys., 161, 565-587.

Tables

\begin{tabular}{|l|l|l|l|l|l|l|l|l|l|}
\hline $\begin{array}{l}\text { Event } \\
\text { Nbr }\end{array}$ & Name & LAT $\left(^{\circ}\right)$ & LON $\left(^{\circ}\right)$ & Date & Mw & $\begin{array}{l}\text { Intensity } \\
(\mathrm{MS})\end{array}$ & Type & $\begin{array}{l}\text { Tsunami } \\
(\mathrm{Y} / \mathrm{N})\end{array}$ & Reference \\
\hline 01 & $\begin{array}{l}\text { Beni } \\
\text { Ouartilane }\end{array}$ & 36.44 & $04.76 \mathrm{E}$ & $10 / 11 / 2000$ & 5.8 & - & $\begin{array}{l}\text { Pure reverse } \\
\text { faulting }\end{array}$ & $?$ & $\begin{array}{l}\text { Bouhadad et al., } \\
2003\end{array}$ \\
\hline 02 & Laalam & 36.56 & $05.41 \mathrm{E}$ & $20 / 03 / 2006$ & 5.6 & - & Strike-slip & $?$ & $\begin{array}{l}\text { Beldjoudi et al., in } \\
\text { press }\end{array}$ \\
\hline 03 & Djidjelli & 36.82 & $05.79 \mathrm{E}$ & $21-22 / 08 / 1856$ & 7 & $\mathrm{X}$ & - & $\mathrm{Y}$ & Harbi, 2006 \\
\hline 04 & Constantine & 36.57 & $06.65 \mathrm{E}$ & $27 / 10 / 1985$ & 6.0 & - & Strike-slip & $\mathrm{N}$ & $\begin{array}{l}\text { Bounif et al., } \\
1987\end{array}$ \\
\hline 05 & N. Seraidi & 37.08 & $07.06 \mathrm{E}$ & $27 / 12 / 1722$ & $?$ & $\mathrm{X}$ & - & $?$ & Harbi, 2006 \\
\hline
\end{tabular}

Table 1. Main earthquakes reported in the Djidjelli-Annaba region. Numbers refers to events shown on Figure 4.

\begin{tabular}{|c|c|c|c|c|c|c|c|c|c|c|c|c|c|c|c|c|}
\hline \multirow{2}{*}{\begin{tabular}{|l}
$\begin{array}{l}\text { Sca } \\
\text { rp }\end{array}$ \\
Sca \\
rp, \\
sect \\
ion
\end{tabular}} & \multicolumn{6}{|l|}{$A$} & \multicolumn{4}{|l|}{$B$} & \multicolumn{4}{|l|}{$\mathrm{D}$} & \multicolumn{2}{|l|}{ C } \\
\hline & A47 & A38 & A49 & A37 & A44 & $\begin{array}{l}\text { A } \\
50\end{array}$ & B37 & B44 & B51 & $\begin{array}{l}\text { B50 } \\
- \\
\text { B43 }\end{array}$ & $\begin{array}{l}\text { D5 } \\
8\end{array}$ & \begin{tabular}{|l} 
D5 \\
6
\end{tabular} & $\begin{array}{l}\text { D5 } \\
5\end{array}$ & D54 & C52 & C53 \\
\hline H 1 & \begin{tabular}{|l|}
400 \\
$\mathrm{~ms}$ \\
300 \\
$\mathrm{~m}$ \\
\end{tabular} & \begin{tabular}{|l|}
280 \\
$\mathrm{~ms}$ \\
210 \\
$\mathrm{~m}$
\end{tabular} & \begin{tabular}{|l}
350 \\
$\mathrm{~ms}$ \\
262 \\
$\mathrm{~m}$ \\
\end{tabular} & \begin{tabular}{|l|}
350 \\
$\mathrm{~ms}$ \\
262 \\
$\mathrm{~m}$ \\
\end{tabular} & \begin{tabular}{|l|}
250 \\
$\mathrm{~ms}$ \\
187 \\
$\mathrm{~m}$ \\
\end{tabular} & $?$ & $\begin{array}{l}<60 \\
\mathrm{~ms} \\
<45 \\
\mathrm{~m} \\
\end{array}$ & $\begin{array}{l}120 \\
\mathrm{~ms} \\
90 \\
\mathrm{~m} \\
\end{array}$ & \begin{tabular}{|l|}
250 \\
$\mathrm{~ms}$ \\
187 \\
$\mathrm{~m}$ \\
\end{tabular} & \begin{tabular}{|l|}
260 \\
$\mathrm{~ms}$ \\
195 \\
$\mathrm{~m}$ \\
\end{tabular} & \begin{tabular}{|l|}
40 \\
$\mathrm{~ms}$ \\
30 \\
$\mathrm{~m}$ \\
\end{tabular} & $\begin{array}{l}50 \\
\mathrm{~ms} \\
37 \\
\mathrm{~m} \\
\end{array}$ & $\begin{array}{l}60 \\
\mathrm{~ms} \\
45 \\
\mathrm{~m}\end{array}$ & $\begin{array}{l}<50 \\
\mathrm{~ms} \\
<37 \\
\mathrm{~m} \\
\end{array}$ & $\begin{array}{l}>23 \\
0 \\
>17 \\
2 \mathrm{~m}\end{array}$ & \begin{tabular}{|l|}
320 \\
$\mathrm{~ms}$ \\
240 \\
$\mathrm{~m}$ \\
\end{tabular} \\
\hline H 2 & - & - & $\begin{array}{l}90 \mathrm{~m} \\
\mathrm{~s} \\
67 \mathrm{~m}\end{array}$ & $\begin{array}{l}50 \\
\mathrm{~ms} \\
37 \\
\mathrm{~m} \\
\end{array}$ & \begin{tabular}{|l|}
48 \\
$\mathrm{~ms}$ \\
36 \\
$\mathrm{~m}$ \\
\end{tabular} & ? & 0 & 0 & \begin{tabular}{|l}
150 \\
$\mathrm{~ms}$ \\
112 \\
$\mathrm{~m}$
\end{tabular} & $\begin{array}{l}80 \\
\mathrm{~ms} \\
60 \\
\mathrm{~m} \\
\end{array}$ & $\begin{array}{l}15 \\
\mathrm{~ms} \\
11 \\
\mathrm{~m} \\
\end{array}$ & $\begin{array}{l}20 \\
\mathrm{~ms} \\
15 \\
\mathrm{~m} \\
\end{array}$ & 0 & 0 & $\begin{array}{l}>23 \\
0 \\
>17 \\
2 \mathrm{~m}\end{array}$ & - \\
\hline H 3 & - & - & $\begin{array}{l}\sim 1.5 \\
\mathrm{~ms} \\
\sim 0.7 \\
5 \mathrm{~m}\end{array}$ & - & \begin{tabular}{|l}
$3 \mathrm{~ms}$ \\
1.5 \\
$\mathrm{~m}$
\end{tabular} & ? & $\begin{array}{l}\sim 2- \\
10 \\
\mathrm{~ms} \\
\sim 1- \\
7 \mathrm{~m}\end{array}$ & $\begin{array}{l}\sim 2 \\
\mathrm{~ms} \\
\sim 1 \\
\mathrm{~m}\end{array}$ & - & $\begin{array}{l}\sim 2 \\
\mathrm{~ms} \\
\sim 1 \\
\mathrm{~m}\end{array}$ & - & - & - & - & - & - \\
\hline SB & N? & - & $Y$ & ? & $Y$ & - & $\mathrm{Y}$ & $\mathrm{Y}$ & - & $\mathrm{Y}$ & $\begin{array}{l}\mathrm{sm} \\
\text { all }\end{array}$ & $\begin{array}{l}\mathrm{sm} \\
\text { all }\end{array}$ & $\begin{array}{l}\mathrm{sm} \\
\text { all }\end{array}$ & N? & $\mathrm{N}$ & $N$ \\
\hline
\end{tabular}

Table 2. Main vertical throws across scarps identified, and surface breaks (SB) observed in the shallowest parts $(\sim 100 \mathrm{~m})$ of the sections. Heights $(\mathrm{H})$ are given in milliseconds $(\mathrm{ms})$ and meters $(\mathrm{m}) . \mathrm{H} 1$ and $\mathrm{H} 2$ are the vertical offsets from the top of the ridge to the deep basin and to the backlimb of the folds, respectively (see Figure $7 \mathrm{~b}$ as example). $\mathrm{H} 3$ is the maximum vertical offset observed on Chirp lines on single faults, that could be tentatively associated to a single rupture, potentially co-seismic. Scarp Letter and section Number refer to Figure 7a. See text for details. $\mathrm{Y}$ is for Yes, $\mathrm{N}$ for No. 


\section{Figures}

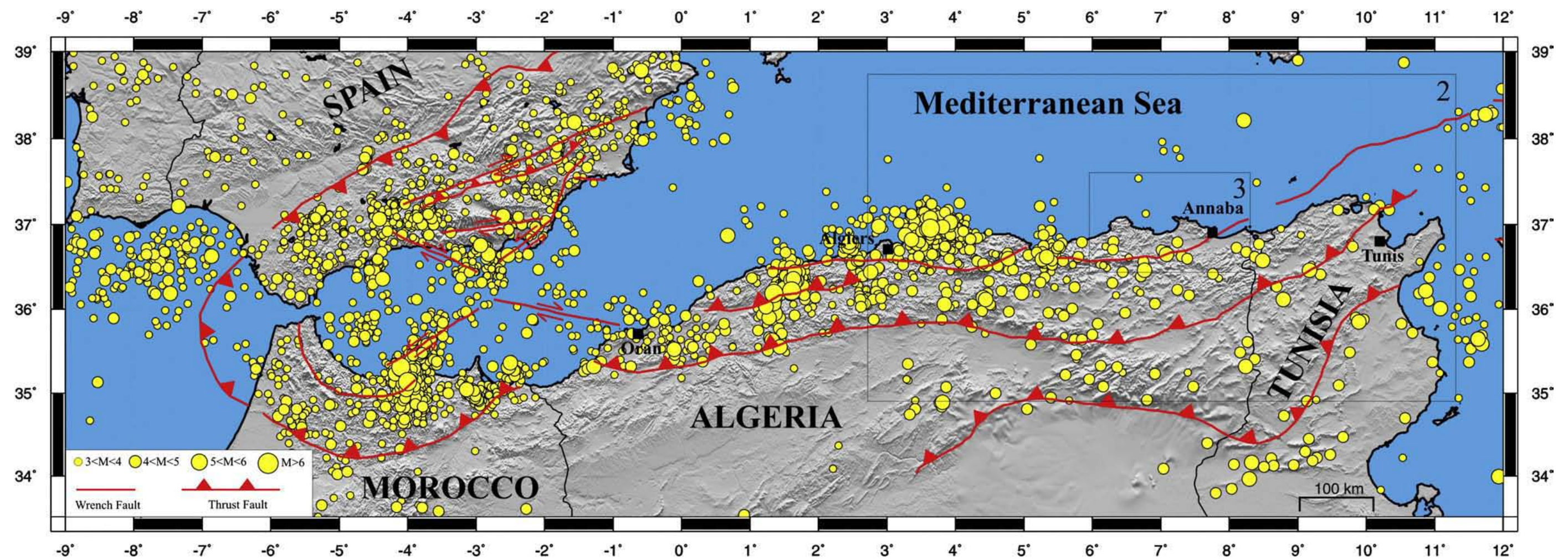

Figure 1 : Seismicity of the Ibero-Maghrebian region (plate limit between NW Africa and Europe) using M>3.0 events taken from the NEIC catalogue (data from January 1973 to December 2007). Topography is from SRTM Digital Elevation Model (Farr et al., 2007) with 90 m resolution. Main wrench faults and thrusts redrawn and simplified after Durand-Delga (1978) and Barrier et al. (2004). Boxes 2 and 3 locates positions of Figures 2 and 3 respectively. 


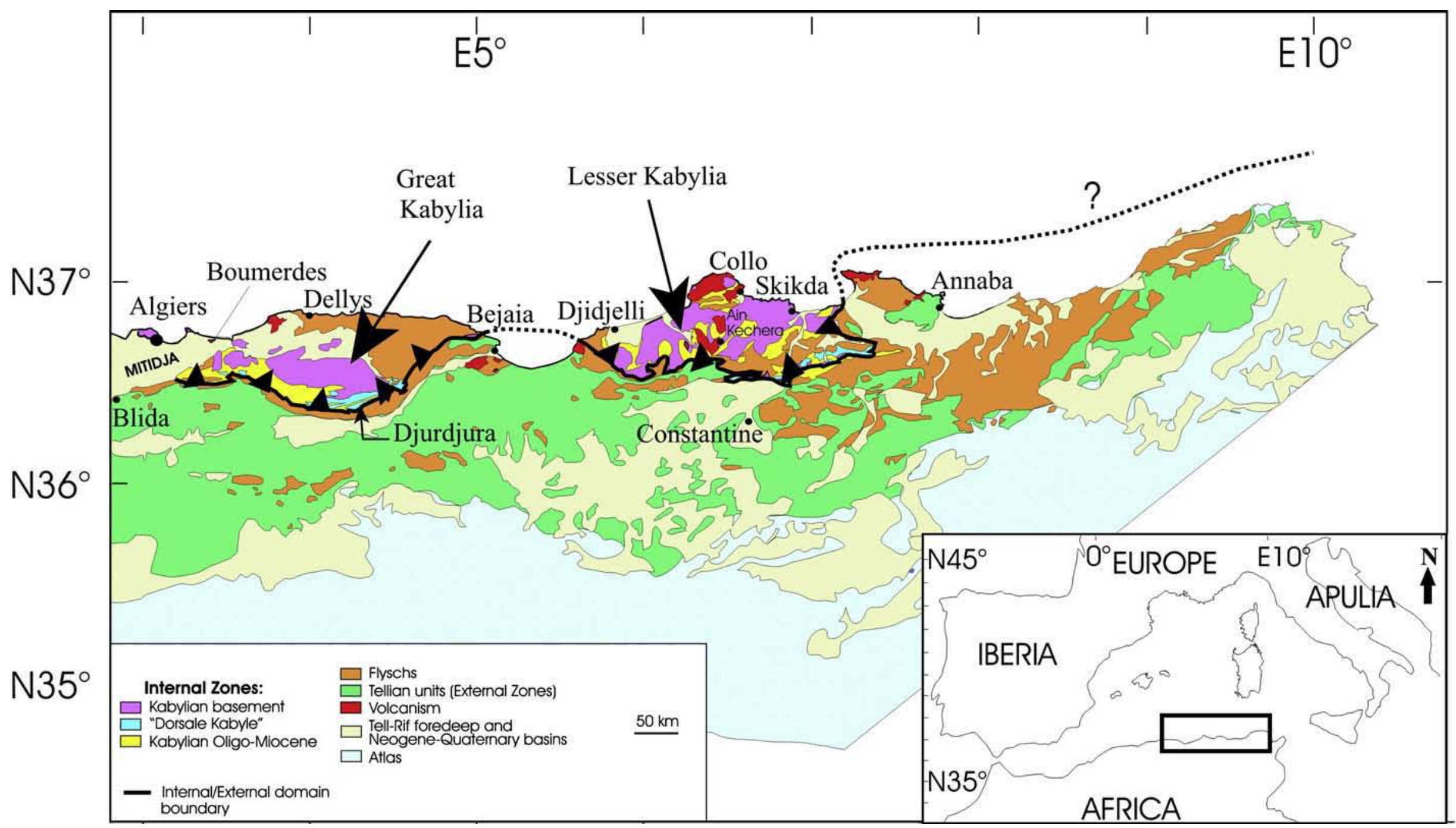

Figure 2: Geological setting of the NE part of Algeria (modified from Domzig et al., 2006). Insets depict captions and global context. Dark line is the suture zone between the Internal and External Zones of the Alpine belt. Dashed line indicates the assumed offshore extent of the thrust front, which is not identified. 


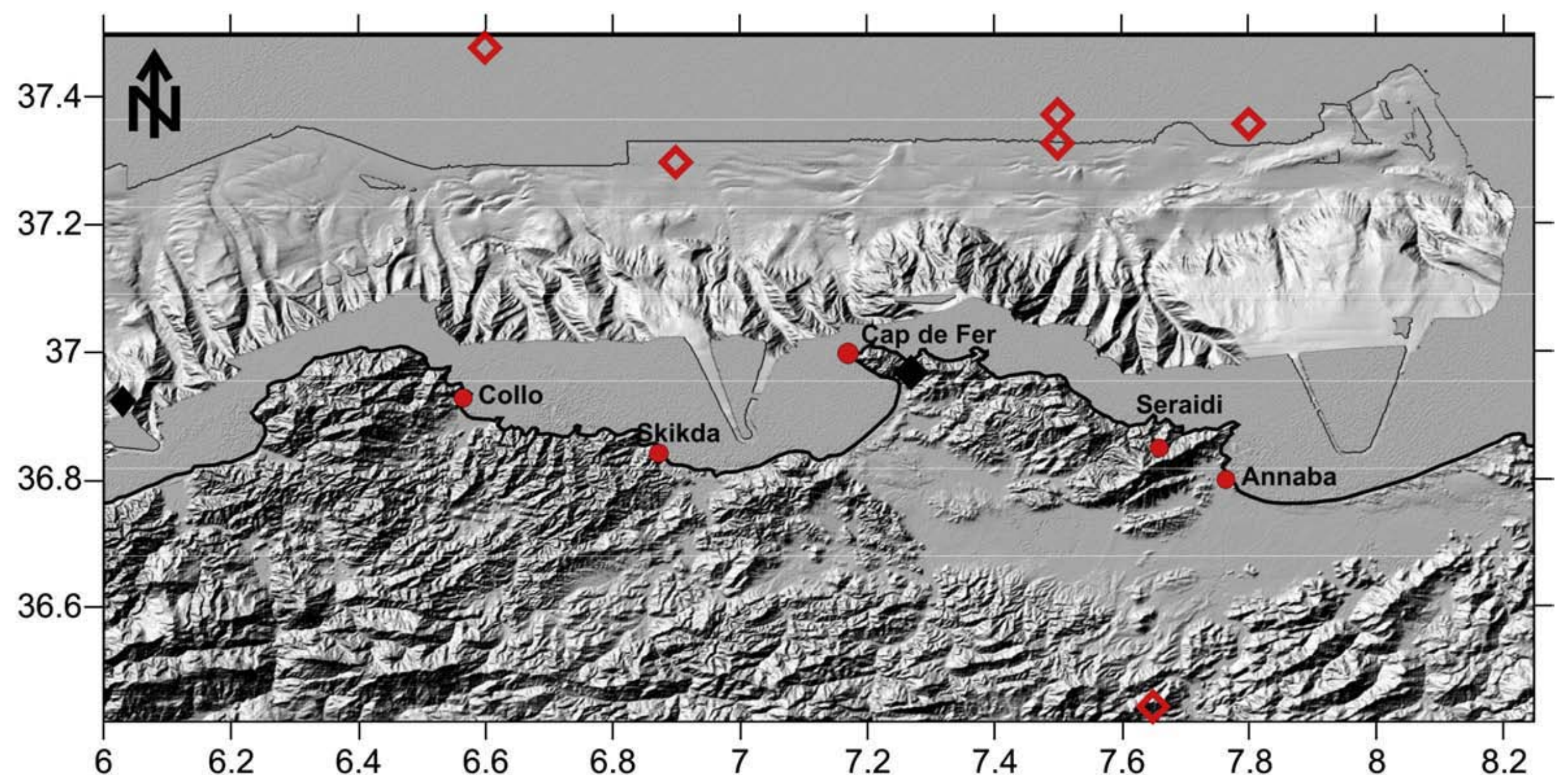

Figure 3: Bathymetric and topographic map of the region of the Lesser Kabylia and historical seismicity (open red diamonds are for intensities ranging from IV to X, and solid black diamonds are of unknown intensity). Topography onland is from DEM SRTM at $90 \mathrm{~m}$ resolution (Farr et al., 2007). Standard errors on epicentre location estimated from catalogues (Harbi, 2006 and references therein) are ranging between 10 and 50 $\mathrm{km}$, depending on their position and time of occurrences. Potential errors on location of historical events offshore are the highest. 


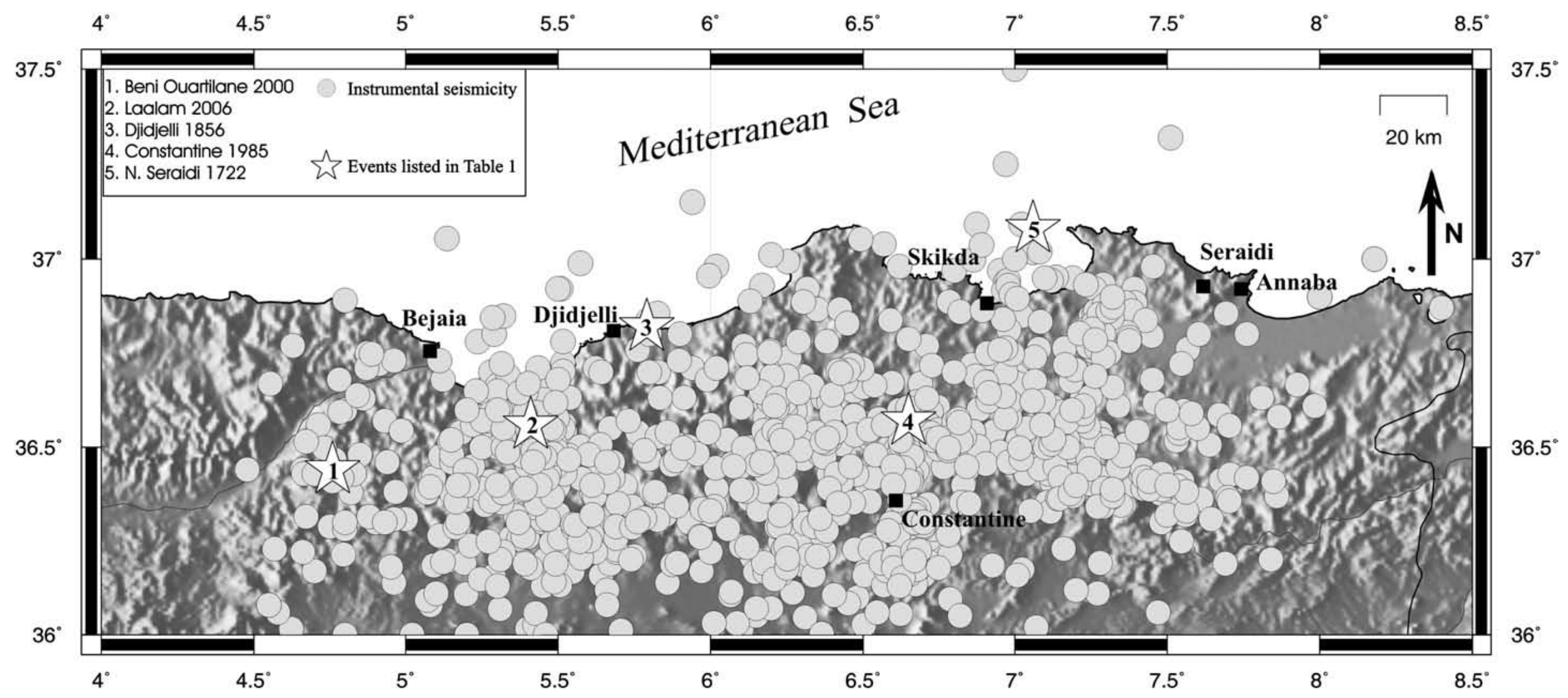

Figure 4: Instrumental seismicity (Catalogue C.R.A.A.G. 1910-2006, $M>1.5$ ) of Lesser Kabylia. Stars with numbers refer to main events of the area 


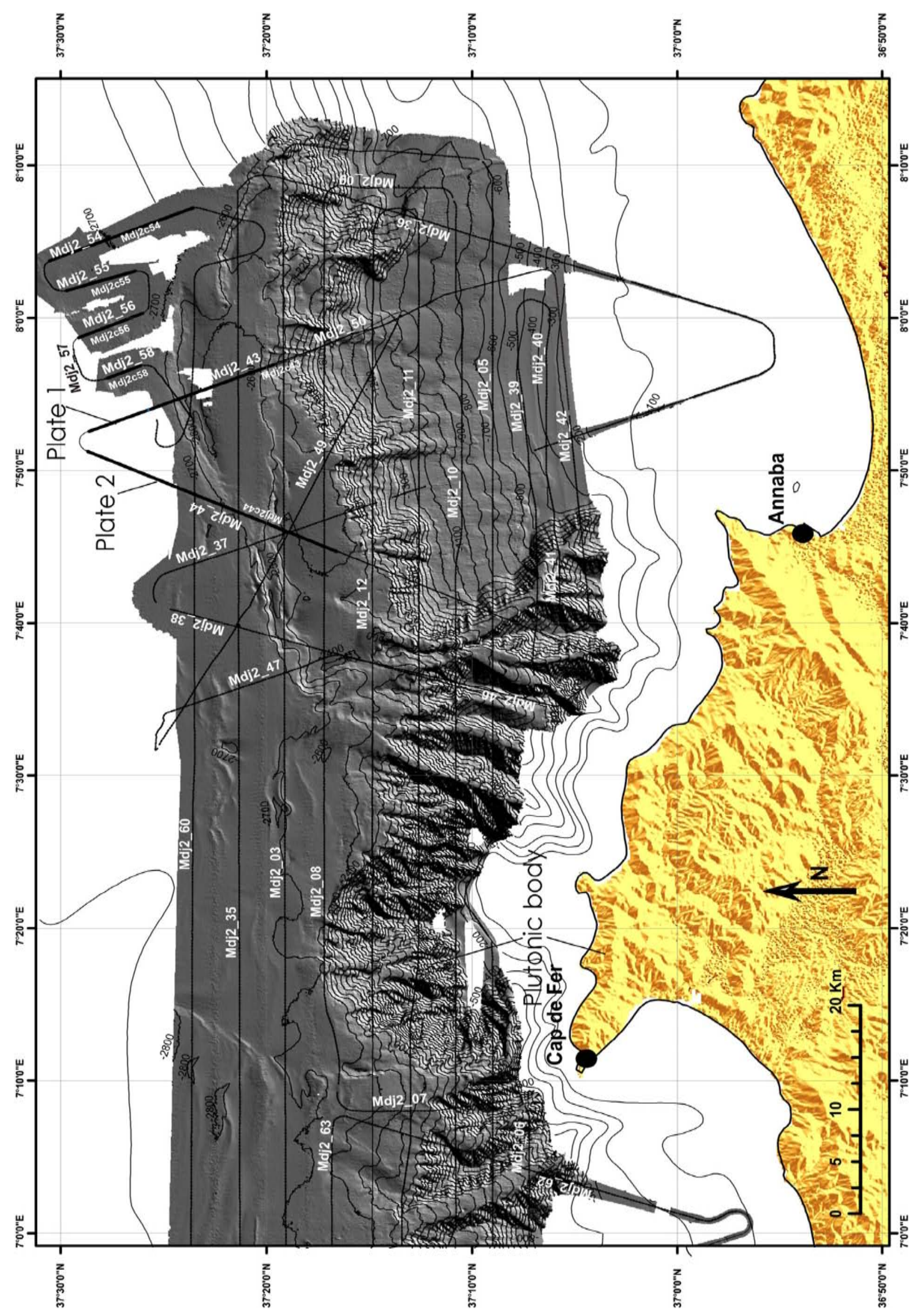


Figure 5: Map of shaded topography available, together with location of seismic and Chirp sections used in this study (thin lines). Bold lines with numbers refer to sections shown on Figures 6 and 7 and on Plates 1 and 2. Contour lines are spaced every $100 \mathrm{~m}$.
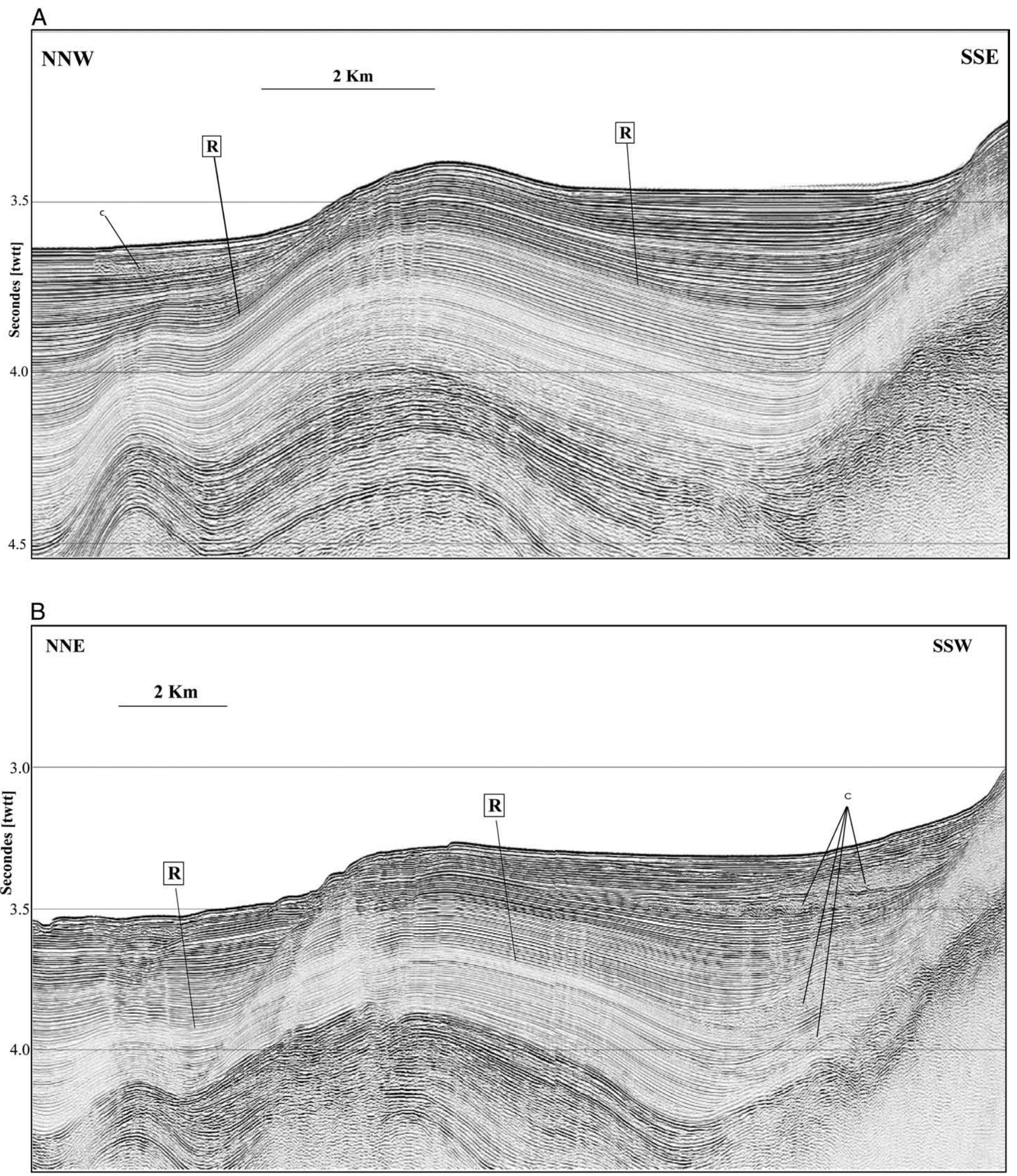

Figure 6: Details (enlargements) of the main folds B and A from seismic sections shown on Plates 1 and 2. a: section MDJ2-43; b: section MDJ2-44 (see location on Figure 5 and line drawings on Plates 1 and 2). Vertical exaggeration (water) is 6 . Reflector $R$ is the limit assumed between pre-growth strata and growth strata on the limbs of active folds (see text 
for details). Note the frequent occurrence of chaotic bodies ("c") interbedded between thin reflectors. They are particularly thick and numerous on the backlimb of Fold A on Section MDJ2-44, at the slope break of the continental margin. twtt = two-way traveltime.

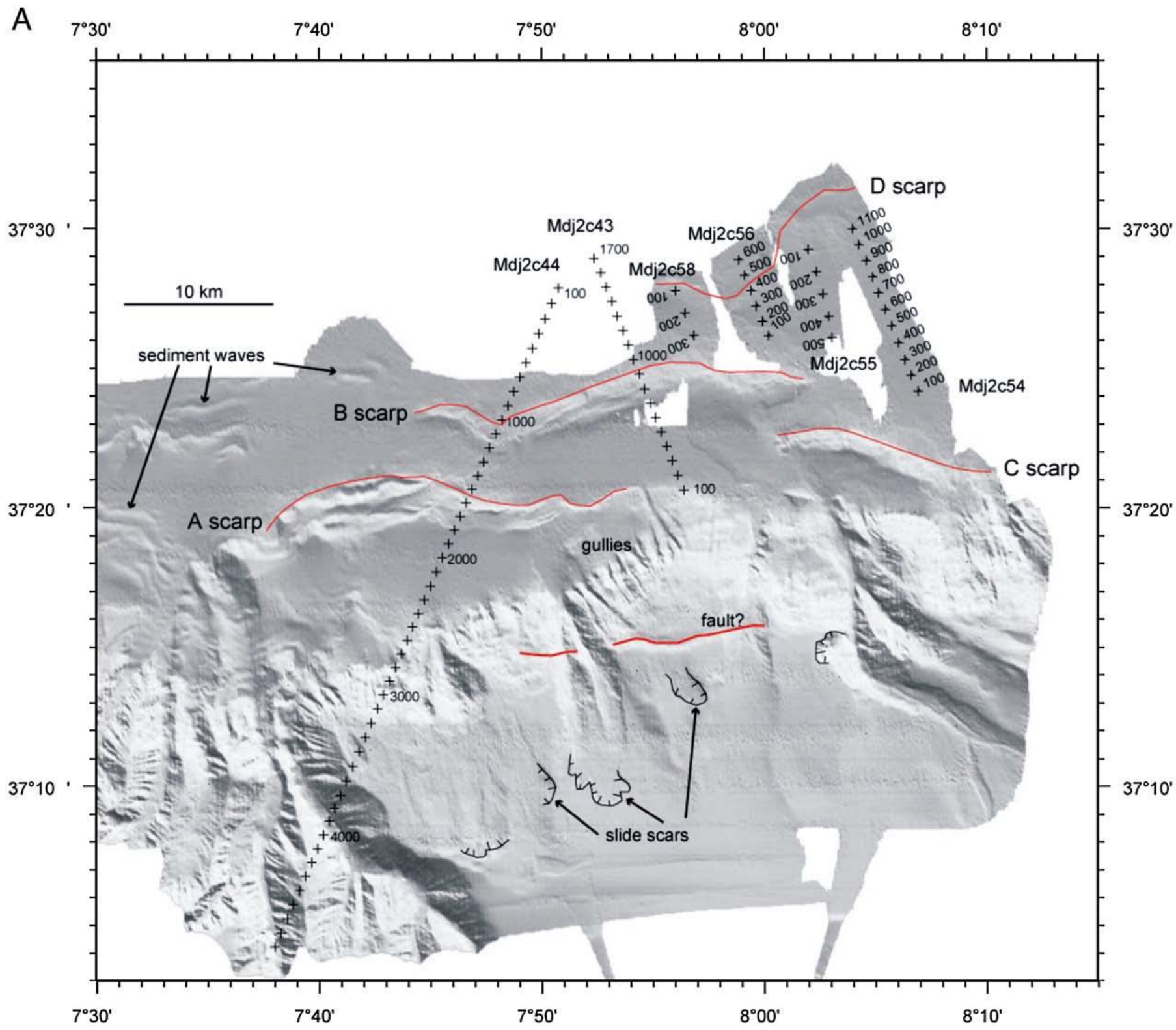




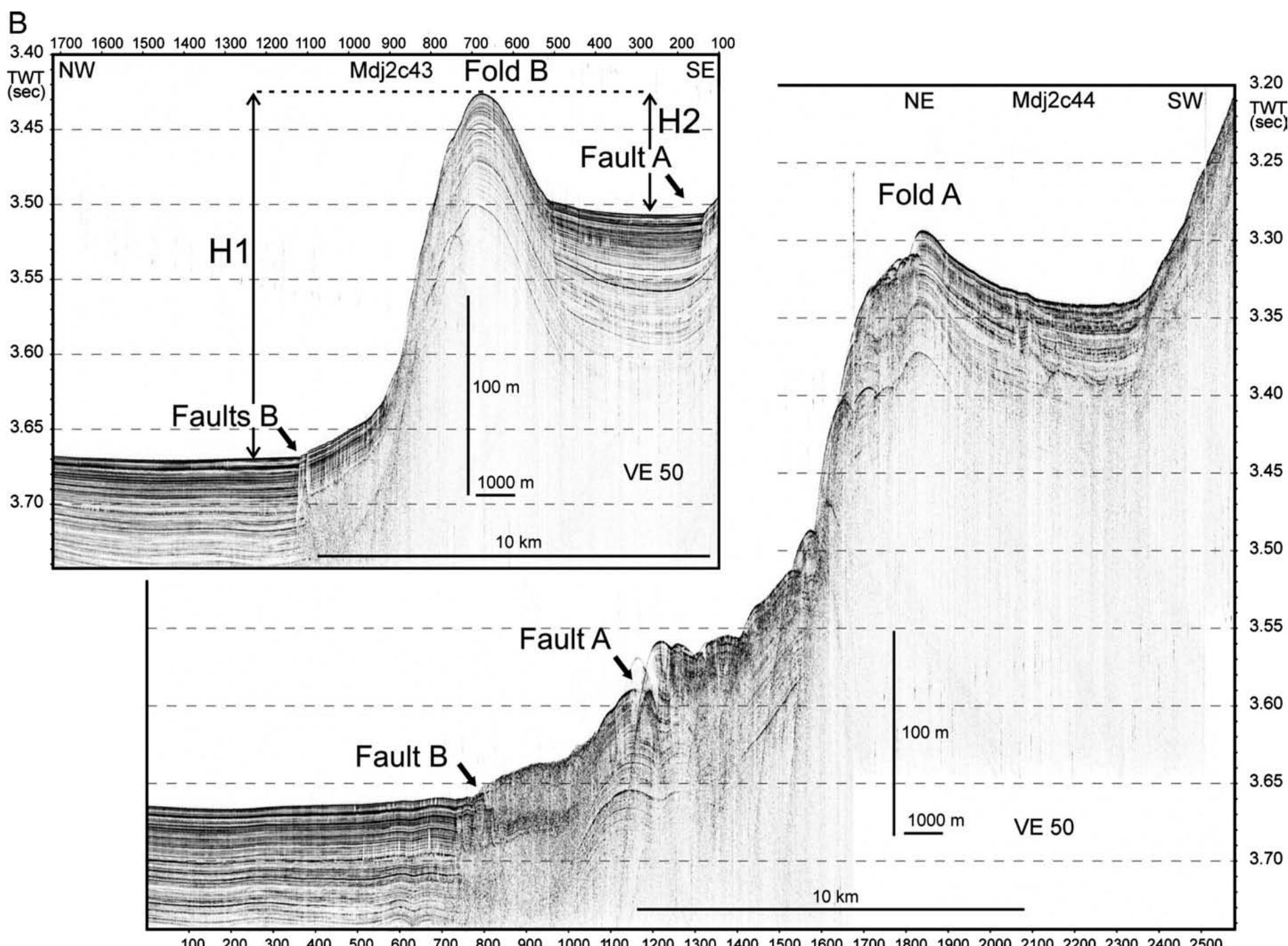

Figure 7: a: Location map of Chirp lines shown with shot points (crosses), scarps (red lines) and slide scars; b. Chirp profiles MDJ2c-43 and MDJ2c-44 along the same track of the multichannel lines imaged on Plates 1 and 2 and on Figure 6 . Letters refer to folds and faults of related scarps. $\mathrm{H} 1$ and $\mathrm{H} 2$ on MDJ2c-43 Line are examples of measurements of cumulative vertical offsets on the forelimb and backlimb of faults as summarized in Table 2 . Small vertical offsets observed at the sea floor (arrows) provide $\mathrm{H} 3$ values reported in Table 2. Vertical exaggeration (VE) is 50. 


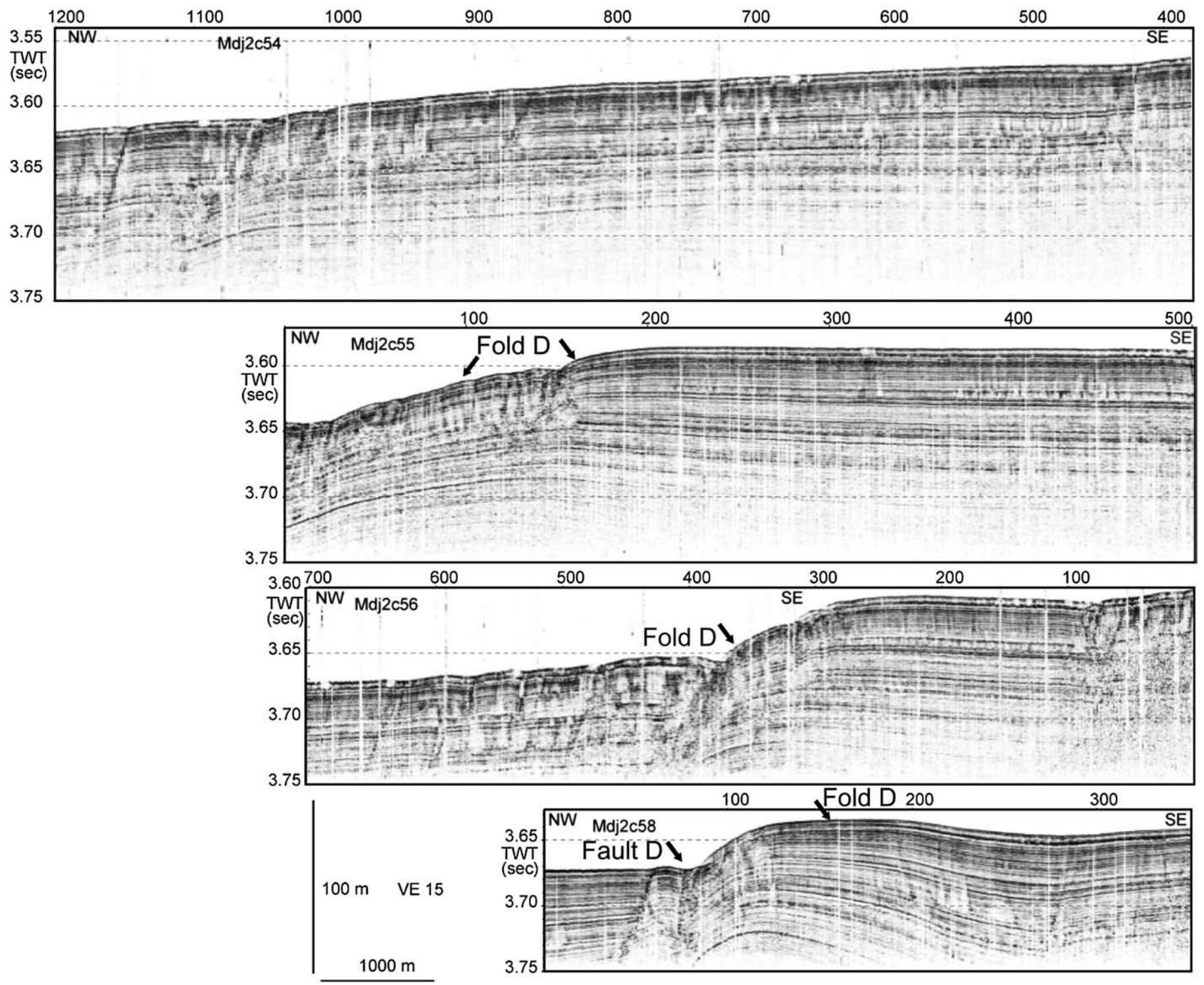

Figure 8: Chirp profiles MDJ2c-54, MDJ2c-55, MDJ2c-56, and MDJ2c-58 across Scarp D (Figures 5 and 7a). These profiles are all parallel one to each other and present the expression of surficial deformation reaching the seafloor. See the exact location of Chirp lines on Figure $7 a$. Letters refer to folds and faults of related scarps. Vertical exaggeration (VE) is 15. 


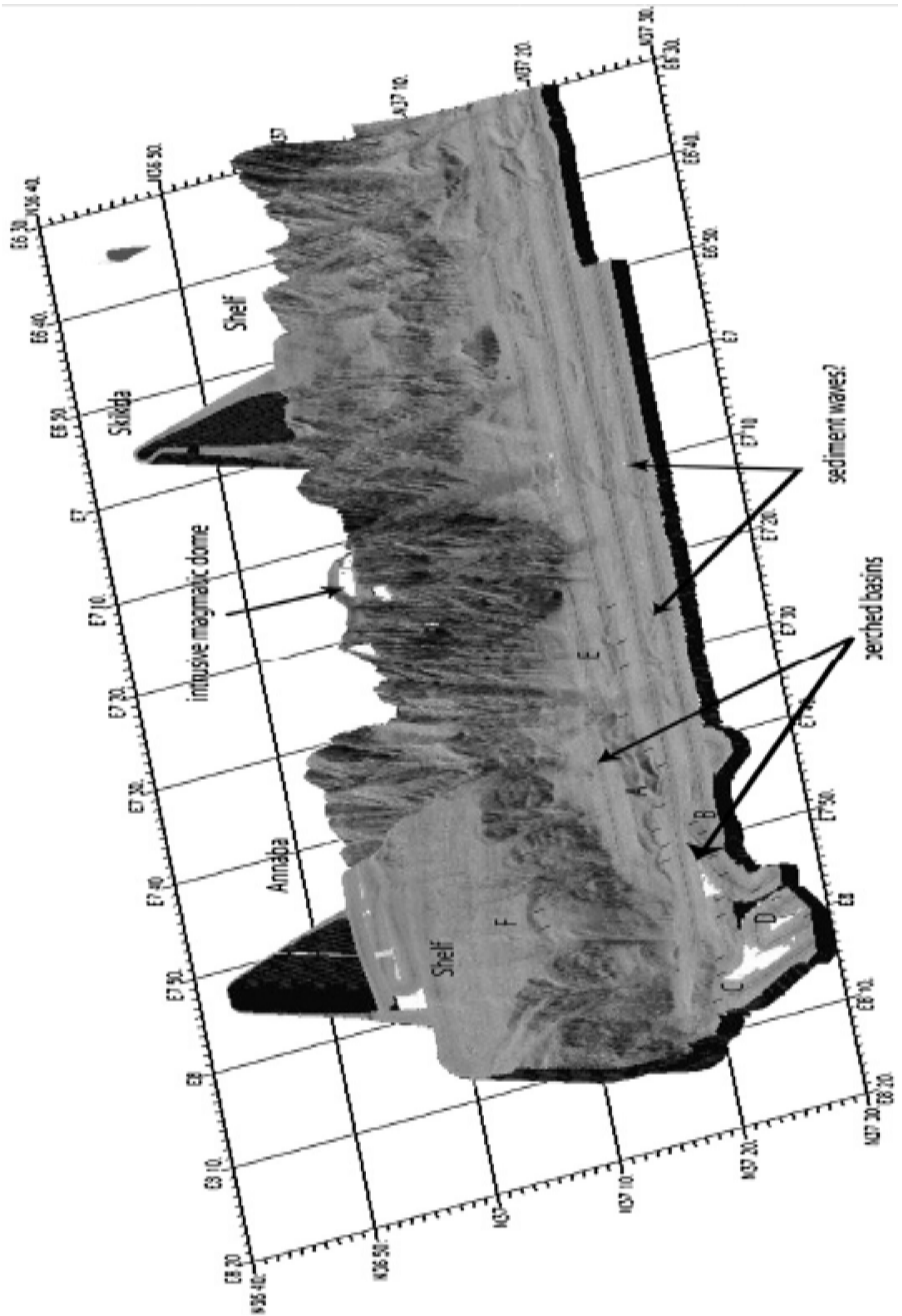

Figure 9. Perspective view from NE to SW of backscattering image plotted on to Digital Elevation Model of the area under study. Letters refer to scarps and folds identified (Figure 7a). Thin, short arrows point the main scarps identified. 


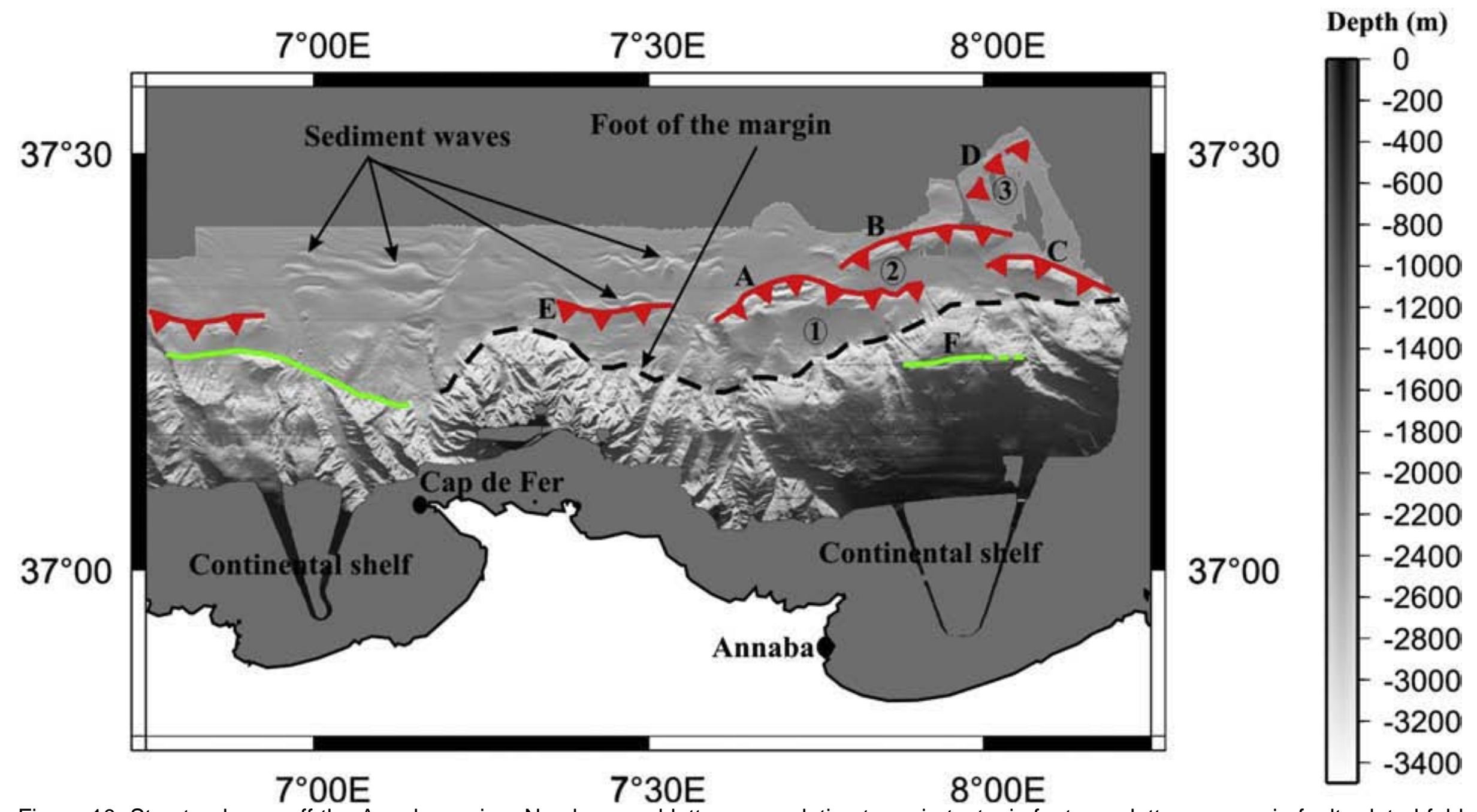

Figure 10: Structural map off the Annaba region. Numbers and letters are relative to main tectonic features: letters are main fault-related folds identified offshore, and numbers 1, 2, 3 are flat surfaces considered here as perched basins on the backlimbs of active folds. From cumulative throws on scarps and sedimentary architecture, Basin 3 appears to be the youngest, and Basin 1 the oldest, among the 3 basins, suggesting a propagation of deformation toward the ocean (see text for details). F depicts a normal apparent throw, as well as the long scarp shown at the 
foot of the western margin (green). Dashed line is the foot of the margin, apparently inactive. Swaying ridges in the deep basin are assumed to represent sedimentary waves, possibly connected to faults (e.g. Scarp E) or to salt diapirism which disturbs the sedimentary distribution.

\section{Plates}




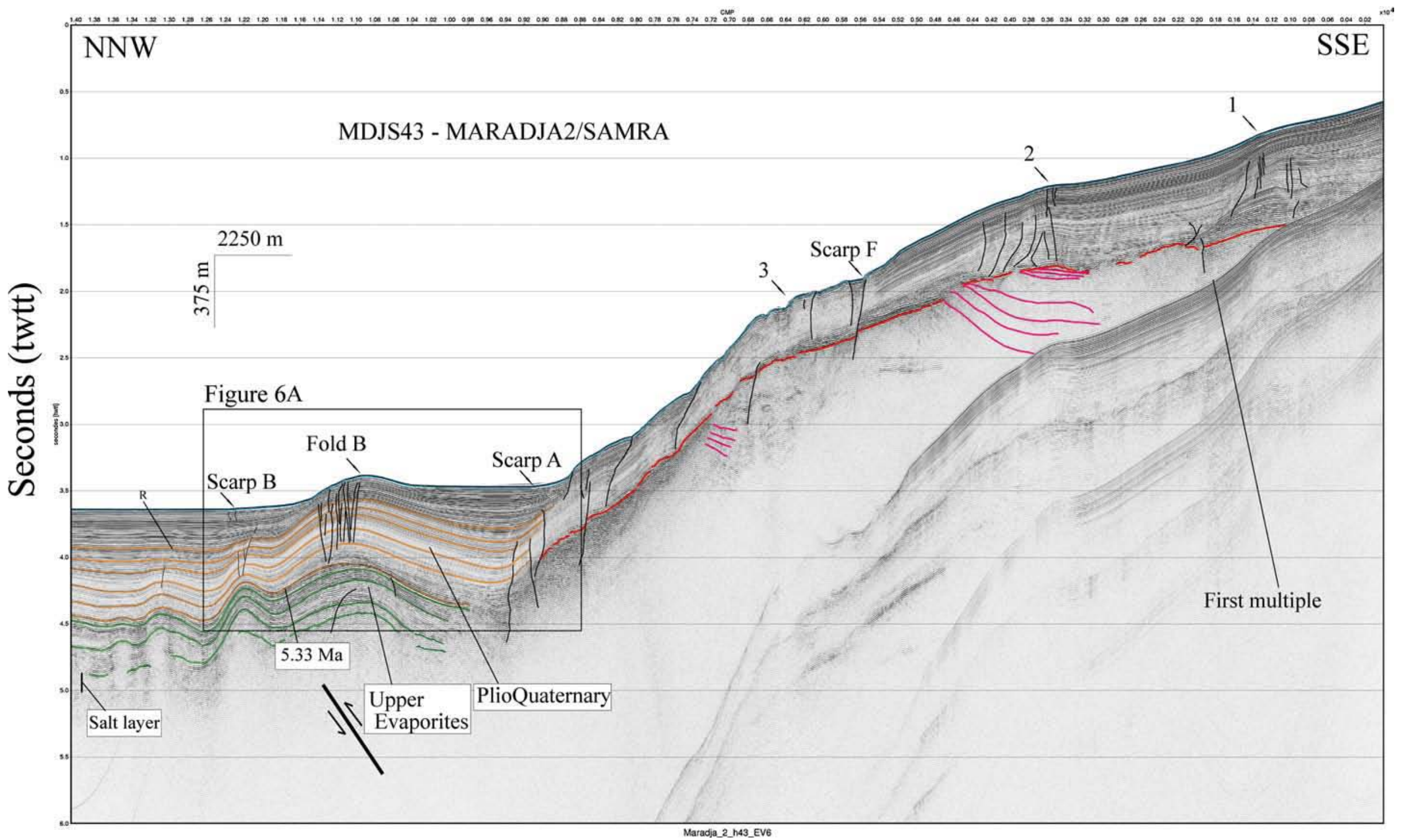

Plate 1: Seismic section MDJ2-43 after stacking and migration, with interpretation (line drawing) on the seismic section. See location on Figure 5 (thick black line). Vertical exaggeration (water) is 6 . Letters denotes scarps observed on Chirp line MDJ2c-43 (Figure 7b). Top of the 
Messinian series is marked at the upper green line (5.33 Ma). Note the asymmetry of the main fold (B), with the steeper flank oceanward. Line with double arrows symbolizes the assumed thrust at depth, although not directly observed. The base of the mobile salt layer is assumed to be near $5 \mathrm{~s}$ twtt.

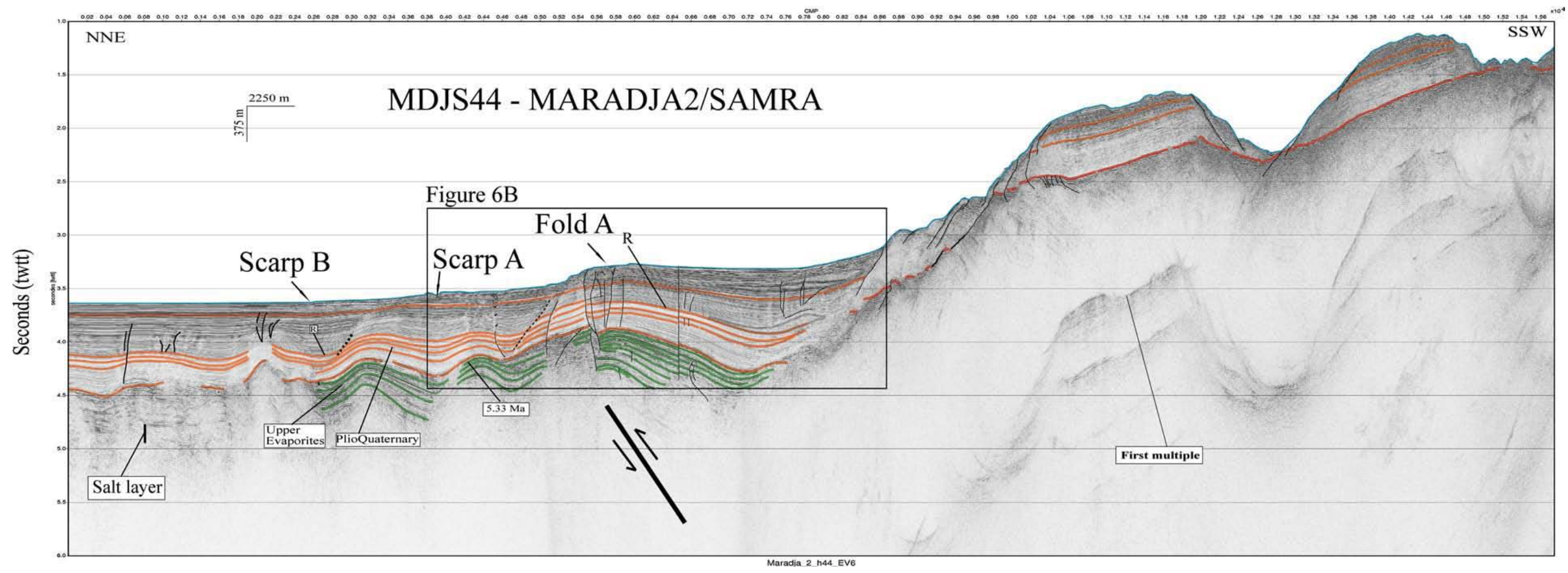

Plate 2: Seismic profile MDJ2-44 after stacking and migration, with interpretation (line drawing) on the seismic section. See location on Figure 5 (thick black line). Vertical exaggeration (water) is 4,5. Letters denotes scarps observed on Chirp line MDJ2c-44 (Figure 7b). Short black arrows denote the shallowest dislocations in the sediments. Note the asymmetry of the main fold $(A)$, with the steeper flank oceanward. Line with double arrows symbolizes the assumed thrust at depth, although not directly observed. Sequences underlined by a grey line are main chaotic bodies identified (Figure 6b). The base of the mobile salt layer is assumed to be close to $5 \mathrm{~s}$ twtt. 